\title{
THE JUDGES REFERENCE AND THE \\ SECESSION REFERENCE AT TWENTY: REASSESSING THE SUPREME COURT OF CANADA'S UNFINISHED UNWRITTEN Constitutional Principles Project
}

\author{
(ALYN) JAMES JOHNSON
}

\begin{abstract}
Upon the 20-year anniversary of the Reference re Remuneration of Judges of the Provincial Court of Prince Edward Island and the Reference re Secession of Quebec, the author reflects on the methodology utilized by the Supreme Court of Canada to reach dramatic conclusions on the basis of unwritten constitutional principles in these cases. An analysis of several decisions leading up to the Judges Reference and the Secession Reference establish a pattern of reasoning from the abstract to the concrete, from unwritten principle to unwritten rule. However, these decisions lack in methodological self-reflection as they utilize unwritten principles to reach particular outcomes without situating the analysis in a larger interpretive framework. The author seeks to clarify this uncertainty by suggesting a methodological framework entitled "reasoning from constitutional essentials." This methodology can assist in understanding the analytical framework used by courts to identify and reach conclusions on the basis of unwritten constitutional principles.
\end{abstract}

\section{TABLE OF CONTENTS}

I. INTRODUCTION . . . . . . . . . . . . . . . . . . . . . . . . . . . 1077

II. Identifying a Constitutional Methodology . . . . . . . . . . . . . 1079

A. OPSEU V. ONTARIO (ATTORNEY GENERAL) . . . . . . . . . . . . 1079

B. REFERENCE RE MANITOBA LANGUAGE RIGHTS _........... 1081

C. NEW BRUNSWICK BROADCASTING CO.

V. Nova SCOTIA (SPEAKER OF THE House OF ASSEMBLY) . . . . . 1082

D. MACMILLAN BLOEDEL LTD. V. SIMPSON _.............. 1086

III. TheORIZING THE Methodology:

REASONING FROM CONSTITUTIONAL ESSENTIALS _........... 1088

IV. THE JUDGES REFERENCE, THE SECESSION REFERENCE, AND THE SUPREME COURT's THEORY OF THE CONSTITUTION . . . . . 1094

A. REFERENCE RE REMUNERATION OF JUDGES OF THE

PROVINCIAL COURT OF PRINCE EDWARD ISLAND . . . . . . . . . . . . 1094

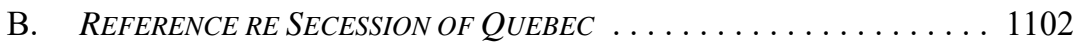

C. THE SUPREME COURT'S THEORY OF THE CONSTITUTION . . . . . . . 1107

V. CONCLUSION: THE SUPREME COURT'S UnFINISHED

UnWRITTEN PRINCIPLES PROJECT $\ldots \ldots \ldots \ldots \ldots \ldots \ldots \ldots \ldots \ldots$

\section{INTRODUCTION}

The twentieth anniversary of Reference re Remuneration of Judges of the Provincial Court of Prince Edward Island; Reference re Independence and Impartiality of Judges of the

PhD in Law (Queen's University); PhD in English Literature (Queen's University); LLB (University of Alberta). Prior to his recent doctoral work in law, James worked for six years as an Associate at Norton Rose Canada LLP in Toronto, and he taught English literature at the university level for five years. This article is adapted from a chapter of his dissertation in Law, "The Canadian Nondelegation Doctrine: An Architectural Imperative.”Comments are welcome at j.johnson@queensu.ca. 
Provincial Court of Prince Edward Island ${ }^{1}$ was 2017 and the twentieth anniversary of Reference re Secession of Quebec ${ }^{2}$ was 2018. In these momentous and controversial judgments, the Supreme Court of Canada broke new ground by formally recognizing that unwritten principles form the core of the Canadian Constitution. The Supreme Court also formally recognized that unwritten legal rules emanating from this extra-textual core can be legitimately employed in constitutional litigation.

In this article, I take the opportunity afforded by the 20-year anniversary for a reassessment. I argue that the significance of the Judges Reference and the Secession Reference is best understood in the context of four prior decisions spanning a period of ten years: (1) Reference re Manitoba Language Rights; ${ }^{3}$ (2) OPSEU v. Ontario (Attorney General); ${ }^{4}$ (3) New Brunswick Broadcasting Co. v. Nova Scotia (Speaker of the House of Assembly); ${ }^{5}$ and (4) MacMillan Bloedel Ltd. v. Simpson. ${ }^{6}$ In each of these earlier decisions, the Supreme Court employs unwritten constitutional principles to reach dramatic conclusions, including halting the operation of constitutional texts and overruling legislation. I argue that in each case an identical interpretive methodology is applied, one that proceeds on pragmatic lines, and that draws out the concrete legal ramifications that must follow from abstract foundational principles.

The Judges Reference and the Secession Reference make use of this same methodology and likewise reach dramatic legal conclusions based on unwritten principles. But in these two later judgments, the Supreme Court also begins the much-needed process of theoretical reflection on how extra-textual sources of authority can legitimately fit into a coherent understanding of the Constitution. This theoretical endeavour is crucial to justifying the judicial role, and is impressive in its broad outlines, but it is only partly successful. The Supreme Court offers a coherent model of the Constitution that accommodates unwritten principles and both written and unwritten rules, but fails to account adequately for the actual formulation of unwritten rules. Ironically, the very method of constitutional interpretation that is employed in all six decisions noted above is not itself brought into the Supreme Court's emerging constitutional theory. While it is possible to speak of an unwritten principles project as a result of the theoretical inroads made in the Judges Reference and the Secession Reference, this impressive endeavour remains incomplete without a clear acknowledgment of the process of generating unwritten legal rules from unwritten principles.

In Part II, below, I analyze the Manitoba Language Reference, OPSEU, New Brunswick Broadcasting, and MacMillan Bloedel, focusing on the precise methodology that the Supreme Court employs when it approaches unwritten sources of constitutional authority. In Part III, I argue that this methodology, which provides a basis on which unwritten rules can be formulated, is theoretically sound and provides a structural approach to the essential features of a democratic constitution. In Part IV, I turn to the Judges Reference and the Secession Reference. I argue first that the Supreme Court uses the same methodology employed in the earlier decisions. Then I consider the ambitious attempt to advance a theory of the Constitution that embraces unwritten principles. 
I should note that I do not present the judgments considered in this article as exhaustive of instances in which the Supreme Court has made use of unwritten principles in constitutional interpretation. There are other decisions, some earlier and some more recent, in which unwritten constitutional principles have been acknowledged or employed. In $R e$ : Resolution to Amend the Constitution, for example, six members of the Supreme Court draw on the unwritten principle of federalism in recognizing an important constitutional convention, ${ }^{7}$ and two dissenting members argue that unwritten principles "have been accorded full legal force in the sense of being employed to strike down legislative enactments." In British Columbia v. Imperial Tobacco Canada Ltd., on the other hand, the Supreme Court reaffirms the importance of unwritten principles in constitutional interpretation, but nevertheless narrows the force of at least one of these principles, the rule of law, as far as challenging legislation is concerned. ${ }^{9}$ My focus in the present investigation is confined to the six decisions itemized previously, culminating with the Judges Reference and the Secession Reference. Together, these judgments mark a particularly significant phase of constitutional development in which the use of extra-textual sources of authority gains considerable momentum and cohesion.

\section{Identifying a Constitutional Methodology}

In this section, I deal with the four key pre-Judges Reference decisions. My concern is isolating the methodology that the Supreme Court uses in its discussion of unwritten constitutional principles, rather than a comprehensive treatment of each judgment. I begin with OPSEU, the second of the four chronologically, as it provides the most succinct statement of the interpretive methodology that I am tracing.

\section{A. OPSEU V. ONTARIO (ATTORNEY GENERAL)}

In this decision, the Supreme Court addressed the constitutionality of legislation limiting the political activities of civil servants. While the issue was resolved pursuant to the division of powers in sections 91 and 92 of the Constitution Act, 1867, ${ }^{10}$ a majority of four (out of six) members of the Supreme Court also briefly considered whether constitutional protection for fundamental political rights can be grounded on unwritten sources of authority. Justice Beetz, writing for the majority, commented as follows:

There is no doubt in my mind that the basic structure of our Constitution, as established by the Constitution Act, 1867, contemplates the existence of certain political institutions, including freely elected legislative bodies at the federal and provincial levels. In the words of Duff C.J. in Reference re Alberta Statutes ... "such institutions derive their efficacy from the free public discussion of affairs..." and, in those of Abbott J. in Switzman v. Elbling ... neither a provincial legislature nor Parliament itself can "abrogate this right of discussion and debate". Speaking more generally, I hold that neither Parliament nor the provincial legislatures

[1981] 1 SCR 753 at 905-909 [Patriation Reference]. Constitutional conventions are unwritten political rules, "based on custom and precedent," that are part of the Constitution but are not legally binding (ibid at $880-84)$.

$8 \quad$ Ibid at 845 , per Justices Martland and Ritchie.

92005 SCC 49 at paras 58-60, 66. I argue that this decision fails to establish a coherent approach to unwritten principles in "Imperial Tobacco and Trial Lawyers: An Unstable and Unsuccessful Retreat" 57:1 Alta L Rev [forthcoming in 2019].

10

(UK), 30 \& 31 Vict, c 3, reprinted in RSC 1985, Appendix II, No 5. 
may enact legislation the effect of which would be to substantially interfere with the operation of this basic constitutional structure. $^{11}$

This statement is obiter, but it nevertheless provides a powerful affirmation of the view, advanced by individual members of the Supreme Court in the prior decisions cited, that political rights are inherent to our system of government and thus have constitutional status. The process of reasoning in this passage is important. Justice Beetz begins with the fairly straightforward observation that the "basic structure of our Constitution ... contemplates the existence of certain political institutions" that are "freely elected." He then reasons on pragmatic lines that such institutions must be supported by fundamental rights of political speech and debate: "such institutions derive their efficacy from the free public discussion of affairs." He concludes by recognizing an unwritten legal rule that constrains legislative power, for "neither a provincial legislature nor Parliament itself can 'abrogate this right of discussion and debate."”

This single paragraph provides a template for the Supreme Court's use of unwritten principles in the other decisions I discuss below. Three points should be stressed. First, an abstract unwritten principle is isolated (in this case, representative democracy) that is both essential to the Canadian Constitution and relevant to the matter at issue. Second, through a process of reasoning, a concrete legal rule is found to be necessarily inherent to the principle in question. Third, the process of reasoning occurs outside of the express provisions of the Constitution. While there may be written authority that is relevant in some circumstances, the reasoning in question is not dependent on any such provisions for its cogency.

The legal rule recognized in OPSEU has in fact been entrenched in section 2 of the Canadian Charter of Rights and Freedoms. ${ }^{12}$ Nevertheless, Justice Beetz is clear that the legal constraint on legislative power also emanates from unwritten sources, that is, from the "basic structure of our Constitution," or what he subsequently refers to as "structural imperatives": "quite apart from Charter considerations, the legislative bodies in this country must conform to these basic structural imperatives and can in no way override them."13

The obiter status of the above passages from OPSEU should not be allowed to obscure their significance. In the Judges Reference, six (out of seven) members of the Supreme Court expressly endorse Justice Beetz's reasoning, observing that "governments cannot undermine the mechanisms of political accountability which give those institutions definition, direction and legitimacy." ${ }^{14}$ Certain legal imperatives, in other words, are implicit in a given set of political arrangements. I turn now to consider a decision in which unwritten legal imperatives operate far beyond the realm of obiter commentary. 


\section{B. REFERENCE RE MANITOBA LANGUAGE RIGHTS}

The issue in the Manitoba Language Reference was profound: the illegality of virtually all of the enacted laws of the province of Manitoba. Section 23 of the Manitoba Act, 1870 provides that " $[\mathrm{t}]$ he Acts of the Legislature shall be printed and published in both [the English and French] languages."15 The Manitoba legislature, however, had consistently ignored this manner and form requirement and enacted statutes only in English. Pursuant to the supremacy clause of the Constitution Act, 1982, the offending legislation had to be struck down: "The Constitution of Canada is the supreme law of Canada, and any law that is inconsistent with the provisions of the Constitution is, to the extent of the inconsistency, of no force or effect." ${ }^{\text {"16 }}$ Ironically then, the imperatives of the written Constitution (the Manitoba Act is itself a constitutional text ${ }^{17}$ ) placed the province in an effective "state of emergency," for there were very few validly enacted laws, and even the central organs of government in many cases had no legal authority to act. ${ }^{18}$

The unanimous Supreme Court dealt with this crisis by looking beyond the text to the "unwritten postulates which form the very foundation of the Constitution of Canada." 19 As in OPSEU, there is a process of legal reasoning that flows from an abstract point of departure:

The Constitution, as the Supreme Law, must be understood as a purposive ordering of social relations providing a basis upon which an actual order of positive laws can be brought into existence. The founders of this nation must have intended, as one of the basic principles of nation building, that Canada be a society of legal order and normative structure: one governed by rule of law. While this is not set out in a specific provision, the principle of the rule of law is clearly a principle of our Constitution. ${ }^{20}$

As the analysis continues, it becomes evident that this unwritten principle, inherent to the very project of constitutionalism as a "purposive ordering of social relations," has concrete legal attributes:

[T] he rule of law requires the creation and maintenance of an actual order of positive laws which preserves and embodies the more general principle of normative order. Law and order are indispensable elements of civilized life. $^{21}$

The unwritten constitutional principle thus gives rise to an unwritten rule, and this rule is then used to counter (or at least temporarily suspend) the express commands of the written texts:

The only appropriate solution for preserving the rights, obligations and other effects which have arisen under invalid Acts of the Legislature of Manitoba and which are not saved by the de facto or other doctrines is to declare that, in order to uphold the rule of law, these rights, obligations and other effects have, and will continue to have, the same force and effect they would have had if they had arisen under valid enactments,

33 Vict, c 3 (Canada) [Manitoba Act].

Being Schedule B to the Canada Act 1982 (UK), 1982, c 11, s 52.

Ibid, 52 and the Schedule.

Manitoba Language Reference, supra note 3 at 747-48, 766-67.

Ibid at 752 .

Ibid at 750-51.

Ibid at 749 . 
for that period of time during which it would be impossible for Manitoba to comply with its constitutional duty under s. 23 of the Manitoba Act, 1870. The Province of Manitoba would be faced with chaos and anarchy if the legal rights, obligations and other effects which have been relied upon by the people of Manitoba since 1890 were suddenly open to challenge. The constitutional guarantee of rule of law will not tolerate such chaos and anarchy. ${ }^{22}$

It is important to keep in mind the legal situation confronting the Supreme Court in the Manitoba Language Reference. Written constitutional texts (section 23 of the Manitoba Act; section 52 of the Constitution Act, 1982) demanded a certain set of legal consequences. These consequences, however, threatened the very structure of the Constitution and therefore legitimated careful judicial scrutiny of that structure, scrutiny that led to the recognition of a specific unwritten rule of sufficient force to hold the express commands of the written texts in abeyance. The reasoning in OPSEU likewise involved a threat to the "structural demands of the Constitution," a threat in the form of legislation (potentially) interfering with political freedoms. In response to that threat, the Supreme Court recognized a legal rule, derived from the abstract constitutional principle of democracy, capable of overruling such predatory legislation should it materialize. In both of these decisions, the products of democratic willformation, either in the form of legislation or constitutional text, are held to be subject to the necessary structural requirements of the political system itself. This conclusion is further supported by New Brunswick Broadcasting.

\section{NEW BRUNSWICK BROADCASTING CO. V. NoVA SCOTIA (SPEAKER OF THE HoUSE OF ASSEMBLY)}

The difficult question in this judgment was whether a decision of the Nova Scotia House of Assembly to deny the media permission to film proceedings could be interrogated pursuant to the guarantee of freedom of expression and freedom of the press under section 2(b) of the Charter. Justice McLachlin (as she then was), who wrote the majority opinion, found that the Charter did not apply to the House of Assembly when it excluded the media, as that decision was taken pursuant to the unwritten constitutional principle of parliamentary privilege. A total of five members of the Supreme Court agreed with the unwritten principles approach, while three looked to express textual provisions. ${ }^{23}$

Justice McLachlin based her conclusion on the effect of the Preamble to the Constitution Act, 1867; the authority of "historical tradition"; and "the pragmatic principle that the legislatures must be presumed to possess such constitutional powers as are necessary for their proper functioning." ${ }^{24}$ My interest is in the "pragmatic" argument, which is given its most succinct formulation in the following passage:

In my view, this privilege is as necessary to modern Canadian democracy as it has been to democracies here and elsewhere in past centuries. The legislative chamber is at the core of the system of representative

$22 \quad$ Ibid at 758 .

23 Justice McLachlin wrote for herself and three other members of the Supreme Court, and Justice La Forest concurred in a separate and very brief opinion. Chief Justice Lamer, on the other hand, relied on the language of section 32(1)(b) of the Charter to find that the House of Assembly is only a component part of the "legislature," and thus is not subject to entrenched rights guarantees. Justices Sopinka and Cory relied on section 1 of the Charter: Justice Sopinka found that any violation of section 2(b) could be upheld as a reasonable limitation; Justice Cory reached the opposite conclusion.

$24 \quad$ New Brunswick Broadcasting, supra note 5 at 374-75. 
government. It is of the highest importance that the debate in that chamber not be disturbed or inhibited in any way. Strangers can, in a variety of ways, interfere with the proper discharge of that business. It follows that the Assembly must have the right, if it is to function effectively, to exclude strangers. The rule that the legislative assembly should have the exclusive right to control the conditions in which that debate takes place is thus of great importance, not only for the autonomy of the legislative body, but to ensure its effective functioning. ${ }^{25}$

The reasoning here follows what should be, based on my previous analyses, a familiar path. The movement is from abstract to concrete. If one accepts the abstract proposition that the Canadian political system is a project of democratic governance, then it follows that a representative institution must exist: the "legislative chamber is at the core of the system of representative government." It further follows that the activities necessary to the "effective functioning" of this institution must have a degree of legal protection. Legislative functions thus give rise to a "right" and a "rule," and furthermore, these legal imperatives must be respected by the other institutions of government:

The Speaker of the House of Assembly of Nova Scotia is of the view that [the right of the media to film proceedings] would interfere with the decorum and the efficacious proceedings of the House and has ruled against it. In doing so, he acts within the ambit of his constitutional power to control attendance in the House. There is no more cause for a court to review that decision than there would be for the legislature to review the decision of a court to exclude activities in the courtroom which it deems to interfere with the business of the court.

Our democratic government consists of several branches: the Crown, as represented by the Governor General and the provincial counterparts of that office; the legislative body; the executive; and the courts. It is fundamental to the working of government as a whole that all these parts play their proper role. It is equally fundamental that no one of them overstep its bounds, that each show proper deference for the legitimate sphere of activity of the other. ${ }^{26}$

Parliamentary privilege emerges as a "pragmatic" necessity out of the very institutional relationships that define the Canadian Constitution, and thus can be understood as a "relational right," to borrow the language of the American constitutional scholar Charles L. Black. ${ }^{27}$ A "relational right," which flows from the essential requirements of a particular system of government, "arises by necessary implication ... as clearly as though it had been specifically stated in the Constitution." 28 It is "fundamental to the working of government," Justice McLachlin stresses, that each institution has a "legitimate sphere of activity" and must be able to control this "core" of operation without interference from the other components of the constitutional structure. In the circumstances of New Brunswick Broadcasting, an express written command of the Constitution (freedom of expression)

Ibid at 387 .

Ibid at 388-89.

Charles L Black, Structure and Relationship in Constitutional Law (Baton Rouge: Louisiana State University Press, 1969) at 18.

28 Ibid. I should clarify that Black is solely concerned with the US Constitution. I am applying his insights to the institutions of parliamentary government. I will have more to say about Black's theories below. 
cannot be applied by the courts to the Nova Scotia House of Assembly due to an inherent aspect (a "relational right") of the parliamentary system itself. One could say that the Charter, if applied, would threaten the very functioning of the institutions of democratic government.

New Brunswick Broadcasting, like the other two decisions discussed above, leads to the conclusion that written texts cannot provide a complete code of constitutional law. As Justice McLachlin explicitly observes:

As a general proposition, can unwritten constitutional privileges inherent to our legislative bodies be justified on the ground of necessity? Putting the matter differently, can our legislative bodies function properly, clothed only with those powers expressly conferred by our written constitutional documents? The answer to this question must, in my view, be negative. ${ }^{29}$

Constitutional "documents" exist alongside a range of unwritten rules, themselves derived from unwritten principles. The unwritten rules and principles are "inherent" to the structure of the Constitution. ${ }^{30}$ The Manitoba Language Reference and New Brunswick Broadcasting provide that unwritten rules can trump constitutional texts in appropriate circumstances, while OPSEU provides that unwritten rules can, again in appropriate circumstances, trump legislative enactments. What are the appropriate circumstances? As I argue in more detail in Part III, the power of unwritten rules is circumscribed by the requirement of a genuine threat to the structure of the Constitution. This stricture is satisfied in each of the above decisions and is also evident in MacMillan Bloedel, which I consider under the next heading. First, two final points regarding New Brunswick Broadcasting should be made, the first relating to nomenclature and the second relating to the other arguments employed by the Supreme Court in the decision.

On the nomenclature point, Justice McLachlin refers to parliamentary privilege as an unwritten constitutional "principle," 31 and also, in the above quoted passages, as a "rule" and an inherent "right." In the interests of consistency with the other decisions discussed in this article, and with the constitutional theory that I discuss in Parts III and IV, I submit that it is appropriate to view parliamentary privilege as either a right or a rule, but not as a constitutional "principle." In each of the other decisions, constitutional principles are treated as being of an abstract nature, and specific legal rules are developed from these principles. The principles themselves, for the most part, cannot be directly applied to resolve legal disputes. The rule of law, for example, is far too abstract on its own to resolve the Manitoba Language Reference, and democracy is far too abstract on its own to lead to the conclusions implied in the obiter comments in OPSEU. Judicial work is required in each case to distill a specific rule from the abstract principles at work. Parliamentary privilege is far more specific and concrete than the rule of law or democracy, or indeed any of the other unwritten principles treated in later decisions such as federalism, the separation of powers, or judicial independence. Parliamentary privilege is virtually ready to use: it commands that the legislature must have the power to control its internal processes and must not be subject to

New Brunswick Broadcasting, supra note 5 at 385.

The word “inherent," it is perhaps worth noting, appears more than a dozen times in Justice McLachlin's opinion, always in connection with parliamentary privilege.

New Brunswick Broadcasting, supra note 5 at 377. 
interference from the courts. This looks like a specific protective rule, not an abstract principle. The unwritten principle at work in New Brunswick Broadcasting is democracy. Justice McLachlin's ruling itself supports this reorientation of nomenclature when she states, in the above quoted passage, "this privilege is as necessary to modern Canadian democracy as it has been to democracies here and elsewhere in past centuries." ${ }^{, 2}$

On the second point, I noted previously that the Supreme Court advances three grounds to resolve the issue in New Brunswick Broadcasting: the effect of the Preamble, "historical tradition," and the "pragmatic" argument. These three grounds are not prioritized in any clear way, and at times the Supreme Court appears to imply that each is adequate on its own to constitutionalize the principle of parliamentary privilege sufficient to resist the claims advanced under the Charter. ${ }^{33}$ I respectfully suggest that the "pragmatic" argument is logically prior: it provides the most compelling explanation for the result reached and informs the other two grounds themselves. Justice McLachlin's analysis of "historical tradition" involves judicial and academic sources that lead precisely to the conclusions advanced under the "pragmatic" argument:

It has long been accepted that in order to perform their functions, legislative bodies require certain privileges relating to the conduct of their business. It has also long been accepted that these privileges must be held absolutely and constitutionally if they are to be effective; the legislative branch of our government must enjoy a certain autonomy which even the Crown and the courts cannot touch. ${ }^{34}$

Institutional relationships define what must exist for a coherent and principled system of democratic government to function in Canada. It is thus hardly surprising to find historical sources that give expression to these structural imperatives. The Supreme Court's argument from "historical tradition" is logically subordinate to the "pragmatic" necessity of privilege.

A similar logic can be said to inform the preambular argument. The Preamble provides that "the Provinces of Canada, Nova Scotia, and New Brunswick have expressed their Desire to be federally united ... with a Constitution similar in Principle to that of the United Kingdom." J5 Justice McLachlin maintains that " $[\mathrm{t}]$ here is no question that this preamble constitutionally guarantees the continuance of Parliamentary governance," 36 and further that "the inherent privileges of Canada's legislative bodies ... fall within the group of principles constitutionalized by virtue of this preamble." ${ }^{37}$ Again, the "pragmatic" argument, which foregrounds the necessary requirements of the Canadian system of representative democracy, explains the alleged effect of the Preamble. Indeed, "[ $[$ ] $]$ his is not a case of importing an unexpressed concept into our constitutional regime, but of recognizing a legal power fundamental to the constitutional regime which Canada has adopted in its Constitution Acts, 1867 to $1982 . " 38$

The Supreme Court expressly interprets New Brunswick Broadcasting as a manifestation of the democratic principle in the Judges Reference, supra note 1 at para 101.

See New Brunswick Broadcasting, supra note 5 at 377, 384-85.

Ibid at 378-79, and see generally 378-85.

Constitution Act, 1867, supra note 10.

New Brunswick Broadcasting, supra note 5 at 375.

Ibid at 377.

Ibid. 
It must be noted, however, that the preambular argument introduces some instability into the decision. Preambles have traditionally been accorded a lower status than the express provisions of an enactment, serving as aids to interpretation of the rest of the text but not having a direct legal effect of their own. ${ }^{39}$ Indeed, seven members of the Supreme Court make this very point in the Patriation Reference about the Preamble itself. ${ }^{40}$

The assertion in New Brunswick Broadcasting that the Preamble "constitutionalized" parliamentary privilege is not accompanied by any explanation of how the informal legal status of preambles generally is to be negotiated. I respectfully submit that the "pragmatic" argument offers a more stable and coherent basis on which to assert the constitutional force of privilege than the quasi-textual status of the Preamble. It is worth noting that Justice La Forest, in his one-paragraph concurring opinion, expressly downplays the role of the Preamble in supporting the unwritten principle of parliamentary privilege and stops far short of allowing that preambular language can "constitutionalize." 41

\section{MACMILLAN BLOEDEL LTD. V. SIMPSON}

The final pre-Judges Reference decision to be discussed is of considerable importance because it actualizes the proposition set out in obiter in OPSEU: unwritten principles can, in appropriate circumstances, overrule legislation.

MacMillan Bloedel addresses the scope of Parliament's power to create an inferior tribunal (in this case, a "youth court"), and to invest such a tribunal with powers traditionally exercised by the superior courts. The Supreme Court unanimously held that the prevailing test for investing provincial tribunals with judicial powers applies to federal tribunals, and further held that this test was met by the impugned legislation. ${ }^{42}$ However, the Supreme Court divided five to four on the question of whether Parliament could, in the process of investing the "youth court" with judicial powers, also remove those powers from the superior courts (the specific power in question was punishing for contempt of court). The majority found that this could not occur as it would violate the "core jurisdiction" of the courts which emanates from, and is essential to, the unwritten principle of the rule of law:

Governance by rule of law requires a judicial system that can ensure its orders are enforced and its process respected. In Canada, the provincial superior court is the only court of general jurisdiction and as such is the centre of the judicial system. None of our statutory courts has the same core jurisdiction as the superior court and therefore none is as crucial to the rule of law. To remove the power to punish contempt ex facie by youths would maim the institution which is at the heart of our judicial system. 4th ed (Markham, Ont: Butterworths Canada, 2002) at 296-99.

Patriation Reference, supra note 7 at 805 : "What, then, is to be drawn from the preamble as a matter of law? A preamble, needless to say, has no enacting force but, certainly, it can be called in aid to illuminate provisions of the statute in which it appears." On the legal status of the Preamble, see also Peter W Hogg \& Cara F Zwibel, "The Rule of Law in the Supreme Court of Canada" (2005) 55:3 UTLJ 715 at $720,728-29$.

$41 \quad$ New Brunswick Broadcasting, supra note 5 at 367-68.

42 MacMillan Bloedel, supra note 6 at paras 26, 94. The relevant test considers whether the transfer of judicial power is adequately integrated within an administrative regime such that it is "merely subsidiary or ancillary to general administrative functions assigned to the tribunal": Re Residential Tenancies Act, 1979, [1981] 1 SCR 714 at 734-36. 
The core jurisdiction of the provincial superior courts comprises those powers which are essential to the administration of justice and the maintenance of the rule of law. It is unnecessary in this case to enumerate the precise powers which compose inherent jurisdiction, as the power to punish for contempt ex facie is obviously within that jurisdiction. ${ }^{43}$

The reasoning isolated in the previous decisions is evident in these passages. There is a movement from abstract to concrete, from unwritten principle to unwritten rule. While the Supreme Court does not refer to the Manitoba Language Reference or New Brunswick Broadcasting here, there are significant points of comparison. The reasoning in both the Manitoba Language Reference and MacMillan Bloedel flows through the rule of law. The rule of law requires not only a system of positive laws (established in the earlier decision) but also an institution to enforce such laws (evident in the above passages). The proposition that the courts must exist to secure a system of legality leads to the conclusion that this institution must have certain necessary and inherent powers over its operations. A concrete and enforceable rule follows: legislation cannot interfere with the "core jurisdiction" of the courts. This rule recalls New Brunswick Broadcasting and Justice McLachlin's observation that it is "fundamental to the working of government" that each of the institutions has a "legitimate sphere of activity" that must have constitutional protection, even in the absence of express textual provisions. ${ }^{44}$ In New Brunswick Broadcasting, the unwritten rule of parliamentary privilege protects the "core" operations of the legislature and trumps the written text of the Charter. In MacMillan Bloedel, the Supreme Court recognizes an unwritten rule protecting the "core" operations of the judiciary, a rule that trumps a legislative enactment. Both decisions stand for the proposition that the structure of the Constitution protects the institutions of government from external threats when they materialize.

It should be stressed that the legal result in MacMillan Bloedel, which is overruling legislation, flows from reasoning that operates outside of the express provisions of the Constitution. There is some discussion of the judicature provisions (sections 96-101) of the Constitution Act, 1867, and later decisions have attempted to recast the reasoning in MacMillan Bloedel as flowing from section $96 .{ }^{45}$ Nevertheless, a careful reading of the majority judgment, written by Chief Justice Lamer, leaves no doubt that section 96 does not perform the work of overruling legislation - that work is done by the unwritten principle

MacMillan Bloedel, supra note 6 at paras 37-38.

Supra note 5 at 389 .

In Trial Lawyers Association of British Columbia v British Columbia (Attorney General), 2014 SCC 59 at paras 33-36, the Supreme Court appears to argue that MacMillan Bloedel was decided on the basis of section 96. For a detailed critical treatment of this interpretation, see my forthcoming article "Imperial Tobacco and Trial Lawyers: An Unstable and Unsuccessful Retreat," supra note 9. 
of the rule of law. ${ }^{46}$ The Chief Justice underlines the centrality of the rule of law to the ruling in a scholarly article written shortly after:

\begin{abstract}
It is important to note that, while s. 96 was integral to the Court's ruling on the validity of the grant of jurisdiction to the youth courts over contempt ex facie by young offenders, it played no direct role in the ruling on the validity of the removal of that same jurisdiction from the superior courts. That ruling, as the passage just quoted makes clear, derives from the rule of law itself and the special role played by the superior courts of general jurisdiction in preserving it. In form, at least, this feature of the decision in MacMillan Bloedel serves to distinguish it from the decision in Crevier in which s. 96 was explicitly invoked in support of the decision to strike down the legislation at issue there.
\end{abstract}

[T] here was no need in Crevier, as there was in MacMillan Bloedel, to go beyond s. 96 in explaining the Court's decision to strike down the legislation. Had there been, I have no doubt that the explanation would have been grounded, as it was in MacMillan Bloedel, in the rule of law and the special role of the superior courts in relation to it. It is precisely in order to preserve the rule of law in the context of the exercise of power by administrative bodies that the supervisory authority of superior courts arose and continues to play such an important role within our legal system. These constitutional commitments can be said to lie at the heart of both of these decisions. ${ }^{47}$

MacMillan Bloedel, like the other decisions considered above, reveals that "constitutional commitments" can be either written or unwritten, and that such "commitments" provide the courts with the power needed to respond to threats to what Justice Beetz refers to in OPSEU as Canada's "basic constitutional structure." 48 The threat in MacMillan Bloedel is to the integrity of the courts and the judicial system. The rule of law provides the basis to formulate an unwritten rule to neutralize this threat by striking down predatory legislation.

\title{
III. Theorizing THE Methodology: REASONING FROM CONSTITUTIONAL ESSENTIALS
}

The Supreme Court's analysis in each of the four decisions considered thus far is noticeably lacking in methodological self-reflection. Rather, each decision makes use of unwritten principles to reach a result, without placing the analysis within a larger interpretive framework. Methodological clarity, always desirable in legal analysis, is particularly

46 The Supreme Court makes the following observation in MacMillan Bloedel, supra note 6 at para 41 [emphasis added]:

In light of its importance to the very existence of a superior court, no aspect of the contempt power may be removed from a superior court without infringing all those sections of our Constitution which refer to our existing judicial system as inherited from the British, including ss. 96 to 101, s. 129, and the principle of the rule of law recognized both in the preamble and in all our conventions of governance.

The particulars of this broad assertion, however, are concretized only in relation to the rule of law. The discussion of section 96 goes to conferring jurisdiction on youth courts, not removing jurisdiction from superior courts (see ibid at paras 9-26). It is the removal of jurisdiction that renders the impugned legislation unconstitutional.

$47 \quad$ Antonio Lamer, "The Rule of Law and Judicial Independence: Protecting Core Values in Times of Change" (1996) 45 UNBLJ 3 at 11 [emphasis added]. The other decision discussed by Chief Justice Lamer is Crevier v Quebec (AG), [1981] 2 SCR 220, in which provincial legislation was struck down as violating section 96 . Supra note 4 at 57. 
important in the area of constitutional interpretation, where the very essentials of the system of government are at issue. Striking down legislation and halting the operation of constitutional texts are maximal expressions of judicial power. The legitimacy of such actions should be supported by a constitutional theory that accounts for unwritten sources of authority and their actual role in interpretation. In this section, I outline such a theory. In the next section, I turn to the Judges Reference and the Secession Reference.

The following passage from the Manitoba Language Reference offers a convenient point of departure for reflection on the role of unwritten principles in constitutional interpretation:

The Constitution of a country is a statement of the will of the people to be governed in accordance with certain principles held as fundamental and certain prescriptions restrictive of the powers of the legislature and government. $^{49}$

The reference to a "statement of the will of the people" appears to suggest a written understanding of constitutionalism: the people "state" their "will" in a definitive, formal, and consciously crafted text. Crucially, however, the "principle" that is "fundamental" to the decision itself, the rule of law, is not written — it is an "unwritten postulate." ${ }^{\text {" Fo }}$ Furthermore, the concrete legal rule that is used to resolve the Manitoba legislation crisis is likewise unwritten. It follows that the "will" of the people includes propositions that have not yet been fully realized. A constitution, in other words, contains both conscious and unconscious meaning. The conscious meaning is always available, memorialized in text; unconscious meaning, on the other hand, is formalized only gradually, when specific circumstances (often threats to the overall constitutional framework) force judicial reflection on the essentials of governance. Out of the crucible of crisis, an unconscious (that is, unwritten) rule recognized by the courts can become a formal part of the "statement of the will of the people."

The methodology in the Manitoba Language Reference, as in New Brunswick Broadcasting, MacMillan Bloedel, and the obiter paragraph from OPSEU, is grounded in the premise that basic principles inhere in a given form of governance, and while these principles are necessarily of an abstract nature, in certain circumstances more specific and embedded legal corollaries can become evident. I will refer to this methodology as "reasoning from constitutional essentials." Reasoning from constitutional essentials involves distilling the concrete legal rules that are required by the abstract principles in order to make the system work in a coherent fashion. This is a "pragmatic" form of analysis, to borrow Justice McLachlin's wording from New Brunswick Broadcasting. Mark D. Walters captures the crucial point when he speaks, in a discussion of the tradition of "unwritten constitutionalism," of "identifying the practical legal implications" that can be drawn from the "forms of constitutionalism to which societies commit themselves." ${ }^{2}$ While the methodology of reasoning from constitutional essentials, as it is used by the Supreme Court

Manitoba Language Reference, supra note 3 at 745.

Ibid at 752 .

Mark D Walters, "Written Constitutions and Unwritten Constitutionalism," in Grant Huscroft, ed, Expounding the Constitution: Essays in Constitutional Theory (Cambridge: Cambridge University Press, 2008) 245 at 261 . See also ibid at 252-54 on the analytical movement between abstract principles and specific rules. 
of Canada, should not be equated with "unwritten constitutionalism," 52 there are at least some commonalities, one of which is that not all of the "pragmatic" or "practical" legal requirements of a political system are inscribed, or indeed can be inscribed, in authoritative written texts. Written texts must operate alongside unwritten sources of meaning to establish the entirety of the legal content of the Canadian Constitution.

Further insight into the methodology of reasoning from constitutional essentials can be found by considering Hans Kelsen's distinction between a "static" and a "dynamic" system of norms. ${ }^{53}$ A "static" system is defined by rational relationships - certain norms have necessary correlations with others, and more concrete norms can be inferred from more abstract ones. A "dynamic" system, by contrast, is defined by willed relationships. In a dynamic system, which Kelsen associates with legal positivism, certain procedural criteria exist to determine the "validity" of a norm, and provided that these criteria are met, a lawmaker can will any content into the norm. Human will is therefore the determining factor in a dynamic system, while human reason is the determining factor in a static system. ${ }^{54}$

Kelsen's taxonomy can be applied to a democratic system of government. A constitutional democracy provides for a decision-making process that channels politically contentious matters into a forum where citizens, through their representatives, can make binding decisions. A network of institutional relationships provides the mechanisms through which these decisions are interpreted and implemented. The norms generated by the decisionmaking process are "dynamic" within the meaning of Kelsen's taxonomy, but the organizing framework of the decision-making process, including the various supporting institutional relationships, is "static." This framework and these relationships are not willed, but rather are inherent to the logic of the system. They offer the necessary stability to an otherwise dynamic arrangement. ${ }^{55}$

While Kelsen identifies morality and natural law as static systems, it does not follow that these two closely related examples are exhaustive. The static norms that organize a democratic system of government are not primarily moral in nature, but rather are structural — they enable the system to function pursuant to its own intrinsic logic. ${ }^{56} \mathrm{~A}$ constitutional democracy can thus be understood as a dynamic and positive norm-producing form of

One important difference is that the Supreme Court of Canada's unwritten principles jurisprudence does not appear to expressly endorse the natural law view that the law must contain certain moral content a view that may be located in some of the authorities discussed by Walters. See also my comments below on natural law and morality in relation to Hans Kelsen's "static" system of norms.

53 Hans Kelsen, General Theory of Law and State, translated by Anders Wedberg (Cambridge, Mass: Harvard University Press, 1949) at 112-14, 399-400.

For all of the points made in this paragraph, see Kelsen, ibid.

Kelsen's own detailed treatments of democracy suggest that he ascribes to the need for certain definitional structural norms, including a "collegial" legislative body, fundamental individual rights, and the judicial review of legislation: see The Essence and Value of Democracy, ed by Nadia Urbinati \& Carlo Invernizzi Accetti, translated by Brian Graf (Lanham, Md: Rowman \& Littlefield, 2013) at 48, 67-68, 80-81; "Kelsen on The Nature and Development of Constitutional Adjudication," in Lars Vinx, ed, The Guardian of the Constitution: Hans Kelsen and Carl Schmitt on the Limits of Constitutional Law (Cambridge: Cambridge University Press, 2015) 22 at 45-49; Hans Kelsen, "Foundations of Democracy" (1955) 66:1 Ethics 1 at 27-28, 38-39.

56 It may be possible to locate moral attributes within the governing norms of a constitutional democracy, and these attributes may in turn add additional coherence to the overall system. This more contentious argument is not necessary to the claims that I am making in this article and is not expressly pursued by the Supreme Court of Canada in the decisions that I am discussing. I leave this matter to others to consider. 
governance surrounded by a static and stable organizational framework. This framework is based on abstract foundational norms, or unwritten principles, such as the separation of powers, the rule of law, judicial independence, and of course, democracy itself. While the norms produced by the system are changeable, the norms supporting the system are fixed.

One of the democratic state's primary institutions is the judiciary. This body has the mandate of protecting the overall architecture of the system, a mandate that flows from, and is nourished by, the fact that only this institution is independent of the decision-making process and the politically contentious matters dealt with therein. In fulfilling its guardianship role, a court can reason from the abstract unwritten principles that organize the system to determine binding concrete rules of a protective nature. These rules are inherent - they are part of the static constitutional structure. It is possible to view this essentially pragmatic process of reasoning as bringing to light, and effectively rendering conscious, the latent or unconscious legal meaning existing within the framework of the constitution.

The process of reasoning from the essential attributes of a democratic constitution has been employed, albeit not under that name, by the American constitutional scholar Charles Black (noted previously in my discussion of New Brunswick Broadcasting). Black maintains that there are two dominant forms of legal interpretation in the Anglo-American tradition: the older method of reasoning from precedent and the more modern method of reasoning from textual enactments. ${ }^{57}$ But he also argues that a third "method" of interpretation is fully legitimate in the area of constitutional law, a method that involves drawing "inference from political structure" and "inference from the structures and relationships created by the constitution in all its parts or in some principal part. ${ }^{258}$ In a discussion of numerous landmark United States Supreme Court decisions, Black demonstrates that results purportedly reached on the basis of constitutional text were in fact derived from "structural" analysis. ${ }^{59}$

Mark Walters and Robin Elliot have both discussed the application of Black's theories to the Supreme Court of Canada's unwritten constitutional principles jurisprudence, although they have reached different conclusions on the subject. Elliot refers to Black's method as "structural argumentation" and defines it as

the drawing of implications from the structures of government created by our Constitution, and the application of the principles generated by those implications - which can be termed the foundational or organizing principles of the Constitution - to the particular constitutional issue at hand. ${ }^{60}$

Elliot, however, expresses concern that this form of reasoning can strain the legitimacy of judicial review if a court moves too far away from enacted constitutional texts. He urges, in particular, that whenever there is an attempt to overrule legislation, any recourse to unwritten principles must also be grounded in textual provisions. ${ }^{61}$ Elliot's approach suggests that legislation, due to its authority as a product of democratic will-formation, should be

Black, supra note 27 at 4-7.

Ibid at 7, 13 .

Ibid at 8-31.

Robin Elliot, "References, Structural Argumentation and the Organizing Principles of Canada's Constitution" (2001) 80:1-2 Can Bar Rev 67 at 68, 116. See also Elliot's discussion of Black's work at 75-77.

61

Ibid at $86,141-42$. 
especially resistant to judicial inquiry grounded on unwritten sources of authority. Walters, on the other hand, situates Black's work within a larger tradition of unwritten constitutionalism and unwritten law leading back to English legal scholars writing in the sixteenth and seventeenth centuries. ${ }^{62}$ In this tradition, texts can never fully embrace a nation's constitution, for they are "evidence of supreme law, rather than ... a single canonical statement of supreme law." ${ }^{63}$ In Walter's analysis, "[t]he constitutional text is not just supplemented by unwritten principles; it rests upon them." ${ }^{64}$ Elliot's strictures regarding the need for a textual warrant to legitimize judicial review when legislation is at issue make no sense in this expansive interpretive framework.

It is certainly not tenable to grant courts licence to review legislation at will, and Elliot's cautions should be heeded. Judicial review that operates within the confines of written constitutional sources of authority respects the proposition that courts have no business interfering with matters that should be dealt with through political institutions. I agree with Elliot that boundaries should be placed around "structural argumentation" — or what I am referring to as reasoning from constitutional essentials. However, I am not convinced that his solution of cordoning off legislation as being beyond the reach of an unwritten principles analysis absent some kind of textual warrant is coherent. The important point is whether there is a threat to the organizing framework of the constitution. If there is, the guardianship role of the courts is engaged, and the source of the threat is irrelevant. Parliamentary sovereignty is an unwritten rule of profound importance, but it is, ultimately, one of many unwritten rules that together enable and protect a democratic constitution. ${ }^{65}$ Elliot's restrictive proposal overlooks the very real prospect that legislatures can violate fundamental constitutional precepts in circumstances where no textual authorities are on point.

A preferable approach is to isolate the constitutional transgressions that are within the reach of an unwritten principles analysis rather than a category of governmental activity that is out of bounds. Neither Black nor Elliot clearly delineates the class of matters that could be subject to "structural argumentation," other than to suggest that these matters are "constitutional" in the broad sense. It is possible, however, to formulate a relatively cogent rubric. Simply put, when there are threats to the "static" framework of democratic government, and in particular when there are threats to the distribution of power between

See Walters, supra note 51 at 261-66, for the discussion of Black, and see more generally 248-54 for the discussion of the earlier English legal theorists. I should note that Walter's understanding of unwritten constitutionalism is not identical to Black's "structural" method. Black is more concerned with the "structure" of a given constitution. Walters is more concerned with the "practical legal implications" of law itself (see ibid at 248-54, 261-66).

Walters, ibid at 273, 275.

Ibid at 264-65.

While Jeffrey Goldsworthy has argued strenuously in favour of the authority of the rule of parliamentary sovereignty in the British Constitution, his claim appears to rest much more on the traditional acceptance of this rule by judges, officials, and commentators than on theoretical cogency (see especially his discussion of the "rule of recognition" in Jeffrey Goldsworthy, The Sovereignty of Parliament: History and Philosophy (Oxford: Clarendon Press, 1999), ch 10). The English jurist Sir John Laws succinctly captures the weakness of an absolute understanding of parliamentary sovereignty in "Law and Democracy" (1995) Public Law 72 at 92:

Ultimate sovereignty rests, in every civilised constitution, not with those who wield governmental power, but in the conditions under which they are permitted to do so. The constitution, not the Parliament, is in this sense sovereign. In Britain these conditions should now be recognised as consisting in a framework of fundamental principles which include the imperative of democracy itself and those other rights, prime among them freedom of thought and expression, which cannot be denied save by a plea of guilty to totalitarianism. 
government institutions or to the process by which law is generated, interpreted, or applied, an unwritten principles analysis should follow. These matters directly implicate constitutional architecture - the decision-making process and the associated web of institutional relationships — and must be managed through the foundational principles informing that architecture. The source of the threat is ultimately immaterial to invoking unwritten principles. Threats can come from the legislature, the executive, or the courts themselves. ${ }^{66}$

The role of constitutional architecture in a democratic society is to establish the framework within which (often intense) political conflict can ensue in a peaceful fashion. Matters that appear to belong within the political realm of conflict will likely not rise to the level of justifying judicial intervention armed with unwritten sources of authority. The four decisions discussed above involve fundamental architectural questions and amply justify recourse to unwritten principles. The Supreme Court follows, in each case, a methodology of reasoning from constitutional essentials. In the next section, I consider the Judges Reference and the Secession Reference, where architectural questions are again addressed on the basis of this same methodology.

I conclude this section by noting that I have chosen to refer to the methodology employed by the Supreme Court as "reasoning from constitutional essentials" rather than "structural argumentation," the latter being Elliot's rendering of Black's method. This choice is guided by two factors. First, as suggested above, I am not convinced that either Black or Elliot has outlined the structural "method" with a desirable degree of specificity. Second, the phrase "reasoning from constitutional essentials" more accurately captures the crucial elements of the methodology: it is a pragmatic analysis that moves from the abstract propositions that define a constitutional democracy to the concrete legal rules necessarily implicit in those propositions. $^{67}$

In MacMillan Bloedel, supra note 6, a threat emanates from the legislature. In the Judges Reference supra note 1, a threat emanates from both the legislature and the executive. For an example of a threat emanating from the judiciary, see Ontario v Criminal Lawyers' Association of Ontario, 2013 SCC 43 [Criminal Lawyers' Association], in which the Supreme Court found that judicial orders mandating the disbursement of public funds violated the separation of powers.

67 I acknowledge that John Rawls uses the phrase "constitutional essentials" in Political Liberalism (New York: Columbia University Press, 2005) at 227-230. My usage, however, is not intended to mirror or rely on his. While there is some overlap in our understandings of the existence of "constitutional essentials," our overall goals are distinct, for Rawls is developing a political and moral theory, and I am pursuing a theory and a methodology of constitutional law. Rawls divides "constitutional essentials" into two classes: (1) the "fundamental principles that specify the general structure of government and the political process," and (2) the "equal basic rights and liberties of citizenship that legislative majorities are to respect" (ibid at 227). The first class bears some resemblance to the architectural "essentials" that I am discussing in this article. The second class, however, is largely beyond the scope of my analysis. Rawls is considerably more interested in the latter class of "essentials," and I am more interested in the former. I offer no comment on the scope of the second class in this article, other than to note that OPSEU, supra note 4, provides for an essential political right derived from principles relating to the political process. It may be possible to argue that the latter class of essentials follows from the former. 


\section{THE JudGes REFERENCE, THE SECESSION REFERENCE, AND THE SUPREME COURT'S THEORY OF THE CONSTITUTION}

The Judges Reference and the Secession Reference are the Supreme Court's most highprofile unwritten principles decisions. This status, even notoriety, follows in part from the importance of the issues raised: the constitutional ambit of judicial independence and the constitutional protocols governing secession. But these decisions are also significant in that they not only make use of unwritten principles in legal analysis but also attempt to outline a theory of the Constitution that can accommodate such extra-textual sources of authority. With the Judges Reference and the Secession Reference, it becomes possible to speak of a constitutional project involving the recognition and use of unwritten principles.

My concern below is first to outline the Supreme Court's use of the methodology of reasoning from constitutional essentials and second to assess the Supreme Court's emerging theory of the Constitution. I divide my analysis into three parts, treating the resolution of each decision separately and the theoretical discussions together.

\section{A. REFERENCE RE REMUNERATION OF JUDGES OF THE PRoVinCIAL COURT OF PRINCE EDWARD ISLAND}

The Judges Reference dealt with the question of the extent to which the independence of the provincial courts is constitutionally guaranteed. There were multiple appeals, from three jurisdictions, involving challenges to the validity of both legislation and executive orders. ${ }^{68}$ While the arguments centred on section 11(d) of the Charter, and while the appeals were ostensibly resolved pursuant to that provision, Chief Justice Lamer, who wrote the majority opinion for six out of seven members of the Supreme Court, determined that it was important to consider "the broader question of whether the constitutional home of judicial independence lies in the express provisions of the Constitution Acts, 1867 to 1982, or [is] exterior to the sections of those documents. ${ }^{\circ 9}$ In pursuit of this larger goal, he engaged in a 27-paragraph prefatory analysis of unwritten principles, the structure of the Constitution, and the Preamble. ${ }^{70}$

I return to the Chief Justice's prefatory analysis in Part IV.C, below. For now, my interest is in the resolution of the appeals. It is important to note, however, that the shift between the 27-paragraph theoretical discussion and the section 11(d) material has created some

The Supreme Court heard two appeals from Prince Edward Island (which began as references before the appellate Court), three from Alberta (which began as motions in criminal trials), and a single appeal from Manitoba (which began as a constitutional challenge launched by the Provincial Judges Association). The appeals involved impugned legislation and executive orders that attempted to reduce the pay of provincial court judges and control certain matters relating to the administration of the provincial courts such as designating sitting days, the residence of judges, and staffing.

69 Judges Reference, supra note 1 at para 1. In a very strongly worded dissent, Justice La Forest expressed "grave reservations" about the Supreme Court considering the question of judicial independence beyond the narrow language of section 11(d) ("an offence") as the matter was not adequately argued by counsel (ibid at paras 297-302). The Supreme Court reasoned, however, that the extended constitutional discussion was required in order to address the civil jurisdiction of the provincial courts, including their role in constitutional litigation (ibid at paras 83, 86, 126-28). The Supreme Court was faced with an "unprecedented situation" in which the constitutional status of provincial court judges had come under "serious strain" in many jurisdictions (ibid at paras 6-7). A wide-ranging analysis was thus arguably appropriate to avoid uncertainty and subsequent litigation on other areas of provincial court jurisdiction. Ibid at paras 82-109. 
difficulties. The bulk of critical attention, including some very negative commentary, has been directed at the former part of the judgment, with the actual mechanics of the very interesting section $11(\mathrm{~d})$ analysis receiving relatively little consideration. ${ }^{71}$ Furthermore, some courts and commentators have been misled by the Chief Justice's approach, which appears - but only appears — to sanction placing extra-textual considerations in a separate compartment from the actual ruling. In Singh v. Canada (Attorney General), for example, the Federal Court of Appeal rejected a separation of powers challenge to legislation in part by stating that

[Chief Justice Lamer] found this doctrine of separation of powers to come from the preamble to the Constitution which provides for "a constitution similar in Principle to that of the United Kingdom".

First it should be observed that these comments concurred in by five other judges in the Judges Reference were obiter dicta as the case was decided on the basis of paragraph $11(\mathrm{~d})$ of the Charter. ${ }^{72}$

Yet Chief Justice Lamer does not mention the separation of powers in his discussion of the Preamble and scarcely mentions the Preamble in his discussion of the separation of powers. While it is possible to argue that the Preamble discussion is obiter, it is not possible to make the same claim about the separation of powers. The unwritten principle of the separation of powers provides the very core of the section 11(d) analysis. At least two commentators, Jean Leclair and David Mullan, also appear to equate the Chief Justice's treatment of the Preamble with his discussion of unwritten principles and advance the view that all this material is technically obiter as the case was decided on the basis of section $11(\mathrm{~d}){ }^{73}$

I maintain that unwritten principles and reasoning from constitutional essentials do all of the heavy lifting in resolving the Judges Reference, with section 11(d) standing by as only the barest of textual warrants - a peg on which to hang a hat fashioned out of the unwritten principles of the separation of powers, judicial independence, and the rule of law. If section 11(d) actually resolved the appeals, one would expect an analysis of this provision and an application of such an analysis to the facts at issue. Yet, in an opinion extending close to 300 paragraphs, Chief Justice Lamer never once quotes section 11(d) or deals with its precise

71 For strongly critical responses, see WH Hurlburt, "Fairy Tales and Living Trees: Observations on Some Recent Constitutional Decisions of the Supreme Court of Canada" (1999) 26:2 Man LJ 181; Jeffrey Goldsworthy, "The Preamble, Judicial Independence and Judicial Integrity" (2000) 11:2 Const Forum Const 60; Jean Leclair, "Canada's Unfathomable Unwritten Constitutional Principles" (2002) 27:2 Queen's LJ 389; Jamie Cameron, “The Written Word and the Constitution's Vital Unstated Assumptions," in Pierre Thibault, Benoît Pelletier \& Louis Perret, eds, Essays in Honour of Gérald-A. Beaudoin (Cowansville, Que: Yvon Blais, 2002) 91. For more positive responses, see David Mullan, "Underlying Constitutional Principles: The Legacy of Justice Rand" (2010) 34:1 Man LJ 73; Vincent Kazmierski, "Draconian but not Despotic: The 'Unwritten' Limits of Parliamentary Sovereignty in Canada" (2010) 41:2 Ottawa L Rev 245; Walters, supra note 51. For very cautious responses, see Elliot, supra note 60; Warren J Newman, “'Grand Entrance Hall,' Back Door or Foundation Stone? The Role of Constitutional Principles in Construing and Applying the Constitution of Canada" (2001) 14 SCLR (2d) 197.

72 [2000] 3 FC 185 at paras 26-27 (FCA), leave to appeal to SCC refused, 27778 (10 August 2000). Leclair, supra note 71 at 395-96; Mullan, supra note 71 at 86, n 56. Post-Judges Reference judicial independence decisions from the Supreme Court have tended to cite the Preamble and section 11(d) together: see Mackin v New Brunswick (Minister of Finance); Rice v New Brunswick, 2002 SCC 13 at paras 34, 37, 71 [Mackin]; Conférence des juges de paix magistrats du Québec v Quebec (Attorney General), 2016 SCC 39 at paras 31, 96. 
language. Furthermore, he explicitly deals with matters that fall outside of this language. The provision itself states that:

11. Any person charged with an offence has the right

(d) to be presumed innocent until proven guilty according to law in a fair and public hearing by an independent and impartial tribunal. ${ }^{74}$

Justice La Forest, in his dissenting opinion of 75 paragraphs, places great weight on this precise wording and argues that it protects judicial independence only to the extent necessary to protect the rights of an accused, that is, a "person charged with an offence":

The guarantee of judicial independence inhering in s. 11(d) redounds to the benefit of the judged, not the judges.... Section 11(d), therefore, does not grant judges a level of independence to which they feel they are entitled. Rather, it guarantees only that degree of independence necessary to ensure that accused persons receive fair trials. ${ }^{75}$

For Justice La Forest, the constitutional ambit of judicial independence is to be found "inhering in s. 11(d)." Additional protection may be desirable as a matter of policy, but is not constitutionally mandated by the language of the Charter and thus should be dealt with by legislatures and not the courts. ${ }^{76}$ By contrast, the level of protection that the Chief Justice advocates for judicial independence extends beyond the ambit of an "offence" and includes the civil and non-criminal constitutional jurisdiction of the provincial courts. ${ }^{77}$

The Chief Justice's dominant critical approach is extra-textual. He does not mine the language of Canada's written foundational texts but rather the structure of the Constitution. The purported section 11(d) analysis moves steadily away from that provision in order to determine the legal rules governing the appeals. A section 11(d) decision, Valente v. The Queen, ${ }^{78}$ does provide the Chief Justice with an important initial distinction between the "individual independence" and the "institutional independence" of the courts. ${ }^{79}$ But Valente does not provide clarification of "institutional independence," which is of primary importance to the analysis in the Judges Reference, so the Chief Justice turns to Beauregard v. Canada. ${ }^{80}$ At this point, section 11(d) recedes from view and does not reappear in any significant way for some time. Beauregard was decided under section 100 of the Constitution Act, 1867, a provision that does not expressly deal with judicial independence and has no obvious application to the provincial courts or to the prosecution of an

Charter, supra note 12.

Judges Reference, supra note 1 at para 329 [emphasis added].

Ibid at paras 333, 344, 350-51.

Ibid at paras 126-29.

[1985] 2 SCR 673 [Valente].

Judges Reference, supra note 1 at paras 118-22.

[1986] 2 SCR 56 [Beauregard]. 
"offence." ${ }^{81}$ But Beauregard does assist in delineating a constitutional concept of the utmost significance:

As I have mentioned, the concept of the institutional independence of the judiciary was discussed in Valente. However, other than stating that institutional independence is different from individual independence, the concept was left largely undefined. In Beauregard this Court expanded the meaning of that term, once again by contrasting it with individual independence. Individual independence was referred to as the "historical core" of judicial independence, and was defined as "the complete liberty of individual judges to hear and decide the cases that come before them". It is necessary for the fair and just adjudication of individual disputes. By contrast, the institutional independence of the judiciary was said to arise out of the position of the courts as organs of and protectors "of the Constitution and the fundamental values embodied in it — rule of law, fundamental justice, equality, preservation of the democratic process, to name perhaps the most important". Institutional independence enables the courts to fulfill that second and distinctly constitutional role. $^{82}$

In isolating the "constitutional role" of the courts, Chief Justice Lamer provides the basis for a pragmatic argument that can resolve the appeals extra-textually, for judicial independence "enables" the courts (all courts, superior and provincial) to perform a task that is definitional to a coherent democratic legal order. The "constitutional role" of the courts involves acting as an "umpire" of the fundamental laws of society, ${ }^{83}$ and in particular, acting as an "umpire" of disputes involving the state. The provincial courts, the Chief Justice stresses, play a role in deciding many state-related disputes, including disputes involving federal-provincial relations, the Charter, and Aboriginal rights and treaties. ${ }^{84}$ To the extent that the provincial courts perform a "constitutional role," they must enjoy institutional independence.

Having introduced the pragmatic argument that will eventually resolve the appeals, the Chief Justice then directs attention to a range of "sources" that can "ground" judicial independence:

The institutional independence of the courts emerges from the logic of federalism, which requires an impartial arbiter to settle jurisdictional disputes between the federal and provincial orders of government. Institutional independence also inheres in adjudication under the Charter, because the rights protected by that document are rights against the state. As well, the Court [in Beauregard] pointed to the preamble and judicature provisions of the Constitution Act, 1867, as additional sources of judicial independence; I also consider those sources to ground the judiciary's institutional independence. Taken together, it is clear that the institutional independence of the judiciary is "definitional to the Canadian understanding of constitutionalism" (Cooper).

But the institutional independence of the judiciary reflects a deeper commitment to the separation of powers between and amongst the legislative, executive, and judicial organs of government: see Cooper... This is

The Constitution Act, 1867, supra note 10, s 100 provides that

The Salaries, Allowances, and Pensions of the Judges of the Superior, District, and County Courts (except the Courts of Probate in Nova Scotia and New Brunswick), and of the Admiralty Courts in Cases where the Judges thereof are for the Time being paid by Salary, shall be fixed and provided by the Parliament of Canada.

Judges Reference, supra note 1 at para 123 [citations omitted] [emphasis added], citing Beauregard, supra note 80 at $69-70$.

83 Beauregard, ibid at 71-72.

84 Judges Reference, supra note 1 at paras 124-29. 
also clear from Beauregard, where this Court noted ... that although judicial independence had historically developed as a bulwark against the abuse of executive power, it equally applied against "other potential intrusions, including any from the legislative branch" as a result of legislation. ${ }^{85}$

The "sources" itemized in these passages range from the purely textual to the purely extratextual. The "judicature provisions" in Part VII of the Constitution Act, 1867 are the most concrete textual provisions cited, but significantly, these sections speak mostly to matters of the appointment and dismissal of judges of various courts and do not directly address independence at all. The Preamble, which is mentioned in the same breath as the judicature provisions, also offers no express reference to judicial independence, and brings with it the problem of its unclear textual status, which I noted in my discussion of New Brunswick Broadcasting and consider further in Part IV.C.2, below. The references to the Charter and to federalism provide more stable grounds for judicial independence, but these references occupy a particularly interesting space in the above passages because they are presented in abstract terms and are not precisely sourced. The Chief Justice refers to the "document" of the Charter, and unlike Justice La Forest, who looks very specifically to the limited source of judicial independence "inhering" in the concrete language of section 11(d), Chief Justice Lamer speaks more generally of "adjudication under the Charter." The Chief Justice's interest is in the general concept of the relationship of the individual and the state as it is mediated by this "document." This is an architectural, as opposed to an explicitly textual warrant: the Charter offers a source for judicial independence based on its function within the overall structure of the Constitution. This function engages the "constitutional role" of the courts, as discussed above. The movement towards abstraction is even more pronounced in the Chief Justice's reference to "jurisdictional disputes between the federal and provincial orders of government." While this source can be located more concretely in sections 91 and 92 of the Constitution Act, 1867, the Chief Justice does not cite these provisions and instead is interested in the abstract "logic of federalism" that is a fundamental structural component of the Canadian Constitution.

The constitutional status of judicial independence appears to find greater support the further the Chief Justice moves from specific written provisions. He is operating in an entirely different interpretive mode than Justice La Forest. Justice La Forest employs the "textual" method outlined by Black. For the Chief Justice, on the other hand, it is the architectural perspective attained by viewing the Constitution as a whole (Black's structural "method") that provides the most compelling warrant for a broad understanding of the need for judicial independence. The architecture of the Constitution provides the institutional logic for controlling "potential intrusions," and the unwritten principle that captures this institutional logic is the separation of powers, which is the final "source" itemized in the above passages. The Chief Justice, with his comments on the Constitution's "deeper commitment to the separation of powers," has worked his way into the same terrain that was explored by Justice McLachlin in her "pragmatic" argument in New Brunswick Broadcasting: "It is fundamental to the working of government as a whole that [the 
institutions] play their proper role. It is equally fundamental that no one of them overstep its bounds, that each show proper deference for the legitimate sphere of activity of the other." ${ }^{\circ 6}$

While Justice McLachlin did not invoke the separation of powers by name in the earlier decision, there is little doubt that her command that each institution of government must "show proper deference for the legitimate sphere of activity of the other" is central to that principle. ${ }^{87}$ The Judges Reference offers further exploration of the degree of institutional separation mandated by the architecture of the Constitution.

Chief Justice Lamer proceeds to draw specific legal rules from the separation of powers to manage legislative and executive "intrusions" into the "legitimate sphere of activity" of the judiciary. The separation of powers, he maintains, "requires" that "the relationships between the different branches of government should have a particular character." ${ }^{\text {" }}$ The relationship between the courts and the other branches, in particular, must be "depoliticized," for in order to act as arbiters of disputes involving the state - that is, in order to perform their "constitutional role" - the courts must be free from external influence or manipulation. ${ }^{89}$ It is from this pragmatic separation of powers requirement of "depoliticization," highlighted as a "constitutional imperative," that the Chief Justice distills the three concrete rules (referred to as "components" of judicial independence) that decide the appeals. ${ }^{90}$ These rules can be stated as follows:

1. Reductions or freezes in judicial salaries must flow from a "special process" that is "independent, effective, and objective."

2. Members of the judiciary cannot engage in any negotiations on matters of remuneration.

3. Judicial salaries cannot fall below a certain minimum level. ${ }^{91}$

These precise legal rules are the inherent legal properties of the more abstract constitutional principle of the separation of powers: "These different components of the institutional financial security of the courts inhere, in my view, in a fundamental principle of the Canadian Constitution, the separation of powers. ${ }^{, 92}$

The Supreme Court does not find the three governing rules in section 11(d). Justice La Forest, in the passage discussed earlier, finds the relevant scope of the constitutional protection for judicial independence "inhering in s. 11(d)." For the rest of the Supreme Court, however, the scope of this protection is said to "inhere" in the "deeper" unwritten source of the separation of powers. The "three components ... flow from the constitutional imperative

New Brunswick Broadcasting, supra note 5 at 389.

In the 2013 decision of Criminal Lawyers' Association, supra note 66 at para 29, the above passage from New Brunswick Broadcasting is quoted as a primary authority on the separation of powers.

Judges Reference, supra note 1 at para 139 [emphasis in original].

Ibid at paras 131, 140-42.

Ibid.

Ibid at paras $133-35$.

Ibid at para 138 [emphasis added]. See also ibid at paras 131-37. 
that, to the extent possible, the relationship between the judiciary and the other branches of government be depoliticized." 93

There are three unwritten principles relevant to the analysis in the Judges Reference, and it is worth briefly considering their interrelationship. The Chief Justice indicates that "judicial independence flows as a consequence of the separation of powers," that he also makes in Cooper v. Canada (Human Rights Commission). ${ }^{95}$ There is a prioritization here, a prioritization that can be best understood by recognizing that both the separation of powers and judicial independence are institutional manifestations of a "deeper" principle still: the rule of law, which was identified by the Chief Justice in the passage quoted above on the "distinctly constitutional role" of the courts. It is, ultimately, the rule of law that gives rise to this "constitutional role." Peter Hogg and Cara F. Zwibel allude to this point when they note that

[t]he Court [in the Judges Reference] was right, with respect, to include the principle of judicial independence in the rule of law, since the principle of constitutionalism depends upon the presence of courts that will adjudicate legal disputes between government and subjects without fear or favour. ${ }^{96}$

At its most fundamental level, the rule of law literally conceives of a society where "all social and political relations are subject to the law." ${ }^{.97}$ The rule of law thus implies a regularization of interactions, especially those involving the state. ${ }^{98}$ In institutional terms, the rule of law absolutely requires, as Hogg and Zwibel note in the above passage, a separation of the judiciary from the other branches of government, for only such a separation can provide the perspective and the power needed to bring the state within the ambit of the law. It is the exercise of this perspective and this power that is the essence of the "constitutional role" of the courts.

It is thus possible to clarify the relationship between the three central constitutional principles at work in the Judges Reference as follows. The rule of law is the governing concept, and demands that all individuals and entities, and particularly the state itself, be subject to law. The separation of powers functions, at least in part, as an institutional manifestation of the rule of law, demanding a certain pragmatic configuration of structural

93 Ibid at para 131 [emphasis in original].

$94 \quad$ Ibid at para 130 .

95 Cooper, supra note 85 ("[t]he constitutional status of the judiciary, flowing as it does from the separation of powers, requires that certain functions be exclusively exercised by judicial bodies" at para 13).

$96 \quad$ Hogg \& Zwibel, supra note 40 at 728 [emphasis added].

$97 \quad$ Rv Nova Scotia Pharmaceutical Society, [1992] 2 SCR 606 at 640 [Nova Scotia Pharmaceutical], citing Jean-Pierre Henry, "Vers la fin de l'État de droit?" (1977) 93 RDP 1207 at 1208.

98 See Nova Scotia Pharmaceutical, ibid (the rule of law embraces both "the proposition that the relationship of the State to the individuals is regulated by law," and a "global conception of the State as an entity bound by and acting through law" at 640-41). See also William E Scheuerman, Between the Norm and the Exception: The Frankfurt School and the Rule of Law (Cambridge, Mass: MIT Press, 1994) at 68-69. 
relationships that must exist for the rule of law to be obtained. ${ }^{99}$ Judicial independence, finally, can be viewed as a particular subset of the separation of powers, for it focuses on the institutional relationships involving the judiciary.

Based on the above discussion, it can be said that the appeals at issue in the Judges Reference are resolved through unwritten principles and in particular through the methodology of reasoning from constitutional essentials. The analysis proceeds through the following propositions. First, the very basic and abstract requirements of a society under law demand that a "constitutional role" be performed by the courts. Second, this rule of law requirement mandates institutional separation. Third, this separation requires "depoliticization." The concrete legal rules emerge from this latter insight, and effectively protect the courts so that they can fulfill their role in protecting the Constitution:

\begin{abstract}
The challenge which faces the Court in these appeals is to ensure that the setting of judicial remuneration remains consistent ... with the depoliticized relationship between the judiciary and the other branches of government. Our task, in other words, is to ensure compliance with one of the "structural requirements of the Canadian Constitution"... The three components of the institutional or collective dimension of financial security, to my mind, fulfill this goal.
\end{abstract}

[T] he institutional independence of the courts is inextricably bound up with the separation of powers, because in order to guarantee that the courts can protect the Constitution, they must be protected by a set of objective guarantees against intrusions by the executive and legislative branches of government. ${ }^{100}$

After Chief Justice Lamer distills the three rules (the "objective guarantees") through a process of legal reasoning that operates at a considerable distance from the express provisions of the written texts, he proceeds to apply his conclusions to the appeals. Section 11(d) resurfaces at this point, but all of the heavy lifting has been done by unwritten principles, which provide both the reason why judicial independence is constitutionally compelling and the precise content of the rules. To suggest, as Elliot does, that the separation of powers functions "simply as an aid to the interpretation" of section 11(d) is far too simplistic. ${ }^{101}$ This is to ignore the primary judicial work done by reflecting on the architecture of the Constitution and the virtual irrelevance of section 11(d) to the bulk of the crucially formative part of the decision. To borrow Black's observation, made in the course of his

The rule of law does not exhaust the content of the separation of powers. The separation of powers also has important affinities with the democratic principle, as is evident in New Brunswick Broadcasting, supra note 5, where institutional separation requires the courts to respect the internal processes of the legislature, and parliamentary privilege is recognized to protect the "legitimate sphere of activity" of legislative bodies. The separation of powers thus functions as an institutional manifestation of the democratic principle in New Brunswick Broadcasting, and an institutional manifestation of the rule of law in the Judges Reference, supra note 1. Judges Reference, ibid at paras 138, 146 [citation omitted] [emphasis added], citing Hunt $v$ T\&N PLC, [1993] 4 SCR 289 at 323. 
structural analysis of important US precedents, "[t]he precision of textual explication is nothing but specious in the areas that matter."102

The three rules that resolve the appeals in the Judges Reference "inhere" in the separation of powers. The Supreme Court's analysis moves from abstract principles to concrete legal rules. This pragmatic approach follows the same path that was blazed in the earlier decisions of OPSEU, the Manitoba Language Reference, New Brunswick Broadcasting, and MacMillan Bloedel. Text is no more required in the Judges Reference than it was in those decisions. The methodology of reasoning from constitutional essentials convincingly demonstrates both that the "constitutional home of judicial independence" is extra-textual and that legally binding protective rules are implicit in this "deeper" source.

\section{B. REFERENCE RE SECESSION OF QUEBEC}

In the Secession Reference, unwritten principles again play a determinative role, this time in answering the following question posed by the Canadian government: "Under the Constitution of Canada, can the National Assembly, legislature or government of Quebec effect the secession of Quebec from Canada unilaterally?"103 The unanimous Supreme Court rendered its judgment in 1998, one year after the Judges Reference, and found that four foundational principles - democracy, federalism, the rule of law and constitutionalism, and the protection of minorities - govern secession and impose a duty to negotiate on all parties where a province expresses a democratically sourced will to secede.

Various commentators have strongly criticized the Supreme Court for wilfully ignoring the text of the Constitution. Patrick Monahan argues that the Supreme Court strained its proper constitutional role by invoking unwritten principles that it chose to balance in its own fashion, rather than giving due respect to the choices embodied in the written text. ${ }^{104}$ Jamie Cameron maintains that the Supreme Court proceeded "as though the text did not matter at all," and states that the duty to negotiate was not recognized by the Supreme Court but rather fabricated for "political purposes." 105 The "deeply troubling" result, Cameron argues, was effectively a judicial amendment. ${ }^{106}$ W.H. Hurlburt likewise claims that the Supreme Court fabricated the duty to negotiate and provided its own constitutional amendment. ${ }^{107}$

The difficulty with these criticisms is that they appear to operate in a vacuum. To argue that the Supreme Court has engaged in an illegitimate act of "judicial balancing" (Monahan) or constitutional amendment (Cameron and Hurlburt) implies an existing constitutional framework that has been violated. Yet none of these commentators explains exactly how the existing text accommodates the possibility of secession. Jean Leclair observes that "[m]ost

\footnotetext{
102 Black, supra note 27 at 29.

103 Secession Reference, supra note 2 at para 2.

104 Patrick J Monahan, "The Public Policy Role of the Supreme Court of Canada in the Secession Reference" (1999-2000) 11:1 NJCL 65 at 75-79.

Cameron, supra note 71 at 104-108, 110-11, 113 .

Ibid at 105-106, 108-11.

Hurlburt, supra note 71 at $184-88$, and especially $187-88$.
} 
commentators and the lawyers who argued the case had considered the amending formula established by Part V of the Constitution Act, 1982 to be applicable to secession." "108 Yet I have not seen a cogent analysis of Part V suggesting that it could determine the issue of secession. ${ }^{109}$ At best, several provisions are implicated. For example, section 38(2) contemplates amendments having an impact on "the proprietary rights or any other rights or privileges of the legislature or government of a province," and section 43(a) contemplates amendments having an impact on provincial boundaries. ${ }^{110}$ It does not follow that an action as monumental as secession should be governed by provisions addressing only a limited effect of secession or that the Supreme Court acted illegitimately in not giving these provisions adequate consideration. The logical reading of the above provisions is that they apply to changes that occur within the existing federal structure of Canada. A fundamental alteration of that structure is not contemplated. Thus the Supreme Court is surely correct in stating that "[i]t is of course true that the Constitution is silent as to the ability of a province to secede from Confederation."

One textual provision that should be noted, however, is section 52(3) of the Constitution Act, 1982: "Amendments to the Constitution of Canada shall be made only in accordance with the authority contained in the Constitution of Canada." 112 OPSEU, the Manitoba Language Reference, New Brunswick Broadcasting, MacMillan Bloedel, and the Judges Reference definitively establish that unwritten principles are part of the Constitution of Canada and further establish that the courts have the authority to address threats to the Constitution through recourse to such principles. Secession, in the absence of clear textual provisions contemplating such a dramatic eventuality, is a powerful threat to constitutional structure. The methodology followed by the Supreme Court to address this threat is reasoning from constitutional essentials.

The Supreme Court begins by isolating four unwritten principles inherent to the architecture of the Canadian Constitution that are implicated by the issue of secession. I offer the following summary of the Supreme Court's lengthy treatment of each principle:

1. The principle of federalism, which is "inherent in the structure of our constitutional arrangements," provides for a strong central government to pursue the national interest and national identity, but also "recognizes the diversity of the component parts of Confederation, and the autonomy of provincial governments to develop their societies within their respective spheres of jurisdiction." 113

Hurlburt provides a useful analysis of some of the parts of the amending formula but not enough to establish that these provisions could be determinative of the issue of secession (supra note 71 at 184-88). Cameron and Monahan offer no analysis of the Part V provisions.

Constitution Act, 1982, supra note 16.

Secession Reference, supra note 2 at para 84.

Supra note 16.

Ibid at paras 55-60. 
2. The principle of democracy "inform[s] the design of our constitutional structure," and provides that each jurisdiction is governed by democratic will-forming institutions that prioritize popular participation and the "discussion and the interplay of ideas" in the process of self-government. ${ }^{114}$

3. The principle of minority rights, "an essential consideration in the design of our constitutional structure," protects language and culture and includes the recognition of and protection for the rights of Aboriginal peoples. ${ }^{115}$

4. The principle of constitutionalism and the rule of law ensures that the relationships between citizens, between citizens and the state, and between the various levels of governments are all controlled by law and is "necessarily predicated on the idea that the political representatives of the people of a province have the capacity and the power to commit the province to be bound into the future by the constitutional rules being adopted." 116

From these principles, or more accurately from the dynamic interaction of these principles, ${ }^{117}$ the Supreme Court identifies four concrete rules:

1. An expression of the popular will of the citizens of a province to secede is both politically and legally significant and cannot be ignored by the rest of the country.

2. A right to unilateral secession does not follow from such an expression of popular will — there is no "absolute legal entitlement" to secede. ${ }^{118}$

3. An obligation to negotiate, binding on all Canadian governments, does arise from an expression of the will to secede.

4. Such negotiations must be conducted pursuant to the four underlying principles. ${ }^{119}$

$114 \quad$ Ibid at paras 61-69.

$115 \quad$ Ibid at paras $79-82$.

116 Ibid at paras 70-78. The rule of law and constitutionalism are closely related. I suggest that it is most useful to view the latter as a specific manifestation of the former, a conclusion strongly supported by the following statement at para 72:

Simply put, the constitutionalism principle requires that all government action comply with the

Constitution. The rule of law principle requires that all government action must comply with the law, including the Constitution.

117 The Supreme Court states that "[ $\mathrm{t}]$ hese defining principles function in symbiosis. No single principle can be defined in isolation from the others, nor does any one principle trump or exclude the operation of any other" (ibid at para 49). This passage should not be read as providing that different principles can never be prioritized (see Monahan, supra note 104 at 78, for this interpretation). Rather, in a given set of facts, different principles can and often will take on different architectural weight. As Leclair observes, the Supreme Court "should not be understood as though it meant that, in a particular situation, no one principle could take precedence over another. Such precedence, however, must be justified" (supra note 71 at 418 ).

118 Secession Reference, supra note 2 at para 97.

119 I should note that the Supreme Court does not clearly itemize these rules. They are embedded in the decision. 
Consistent with the strategy of reasoning from constitutional essentials that I have emphasized throughout this article, these rules are all concrete manifestations of the underlying abstract principles. ${ }^{120}$ The first two rules are very closely related - almost flip sides of the same coin - and arise inexorably from the interaction of all four of the relevant unwritten principles. The basis of the legitimacy of a popular will to secede is the democratic principle, but this principle is itself guaranteed by a federal system of legal obligations that binds different will-forming jurisdictions into a coherent whole. Thus the legitimacy of the will to secede is both enabled and constrained by a constitutional structure that merges provinces into a national whole and ensures that both majority and minority interests have expression and protection:

The relationship between democracy and federalism means, for example, that in Canada there may be different and equally legitimate majorities in different provinces and territories and at the federal level. No one majority is more or less "legitimate" than the others as an expression of democratic opinion, although, of course, the consequences will vary with the subject matter... The function of federalism is to enable citizens to participate concurrently in different collectivities and to pursue goals at both a provincial and a federal level.

Constitutional government is necessarily predicated on the idea that the political representatives of the people of a province have the capacity and the power to commit the province to be bound into the future by the constitutional rules being adopted. These rules are "binding" not in the sense of frustrating the will of a majority of a province, but as defining the majority which must be consulted in order to alter the fundamental balances of political power (including the spheres of autonomy guaranteed by the principle of federalism), individual rights, and minority rights in our society. Of course, those constitutional rules are themselves amenable to amendment, but only through a process of negotiation which ensures that there is an opportunity for the constitutionally defined rights of all the parties to be respected and reconciled. ${ }^{121}$

As the last sentence here makes clear, the third rule follows directly from the previous two. Any right to secede is constrained by the legal structure that enables it, and thus there is an obligation on the party wishing to secede to interact with the other parties of the overall community defined by the Constitution. Similarly, the other parties have an obligation, based on the legally inscribed community that defines them, to interact with the party seeking secession. The duty to negotiate is thus inherent to the interaction of the unwritten principles. It follows that

[t]he clear repudiation by the people of Quebec of the existing constitutional order would confer legitimacy on demands for secession, and place an obligation on the other provinces and the federal government to unwritten norms of federalism, the rule of law, etc., the rules governing secession laid down by the Court are rather specific": Sujit Choudhry \& Robert Howse, "Constitutional Theory and the Quebec Secession Reference" (2000) 13:2 Can JL \& Jur 143 at 155. 
acknowledge and respect that expression of democratic will by entering into negotiations and conducting them in accordance with the underlying constitutional principles already discussed. ${ }^{122}$

The final rule is virtually axiomatic. If the underlying principles define the legal rights and obligations of the parties, these principles must also establish the framework for any political discussions:

The negotiation process must be conducted with an eye to the constitutional principles we have outlined, which must inform the actions of all the participants in the negotiation process.

Those who quite legitimately insist upon the importance of upholding the rule of law cannot at the same time be oblivious to the need to act in conformity with constitutional principles and values, and so do their part to contribute to the maintenance and promotion of an environment in which the rule of law may flourish. ${ }^{123}$

It is important to note that the Supreme Court expressly refrains from going beyond these rules to address even more specific issues such as the content of an appropriate referendum question on secession, the size of a majority vote required to legitimize a will to secede, the shape of post-secession borders, or the management of national debt. These are all held to be political questions, beyond judicial competence. ${ }^{124}$ But precisely because the Secession Reference does not entertain these questions, the claims advanced by commentators such as Cameron and Monahan that the Supreme Court has illegitimately crossed the line between law and politics seem difficult to sustain. ${ }^{125}$ As I stressed earlier, the essential role of a democratic constitution is to provide the legal framework within which self-government through political struggle can occur. If the principles are indeed fundamental to the Canadian Constitution - both Cameron and Monahan acknowledge this point ${ }^{126}$ — such principles must be capable of defining the parameters within which political decisions regarding secession are made. The rules recognized by the Supreme Court flow from the principles and effectively define the architecture of the secession process.

I conclude this discussion of the judicial reasoning at work in the Secession Reference with one final observation. The Supreme Court's restraint in addressing specific political questions surrounding secession suggests the relevance of a fifth unwritten principle to the decision: the separation of powers. ${ }^{127}$ The separation of powers, which demands a "depoliticization" of judicial remuneration in the Judges Reference, also demands a de-

$122 \quad$ Ibid at para 88 .

123 Ibid at paras 94-95 [emphasis in original].

124 Ibid at paras $96-101$.

125 Cameron, supra note 71 at 107-108, 111-13; Monahan, supra note 104 at 90-92.

126 Cameron, ibid at 106; Monahan, ibid at 74.

127 The Supreme Court briefly considers the separation of powers earlier in the decision in rejecting an argument that rendering advisory opinions is outside of the framework of adversarial litigation and thus outside of the constitutional competence of the judiciary: Secession Reference, supra note 2 at paras $12-15$. 
judicialization of political matters in the unique context of the Secession Reference, and thus a refinement in the law of justiciability and enforcement:

The respective roles of the courts and political actors in discharging the constitutional obligations we have identified follows ineluctably from the foregoing observations. In the Patriation Reference, a distinction was drawn between the law of the Constitution, which, generally speaking, will be enforced by the courts, and other constitutional rules, such as the conventions of the Constitution, which carry only political sanctions. It is also the case, however, that judicial intervention, even in relation to the law of the Constitution, is subject to the Court's appreciation of its proper role in the constitutional scheme. ${ }^{128}$

In the Manitoba Language Reference, New Brunswick Broadcasting, MacMillan Bloedel, and the Judges Reference, unwritten rules were enforceable. In the Secession Reference, the Supreme Court steps back from enforcement, due to the political nature of the questions involved, but nevertheless establishes, drawing on the relevant unwritten principles, the governing legal framework through which political actors can proceed.

\section{The Supreme Court's Theory of The Constitution}

As noted previously, the importance of the Judges Reference and the Secession Reference comes not only from their resolution of pressing and fundamental questions of governance through the use of unwritten principles, but also from their enunciation of a general theory of the Constitution that can justify such judicial action. To be successful, such a theory must accomplish at least two tasks. First, it must explain how the overall Constitution accommodates both unwritten and written sources of authority. Second, it must explain the process through which specific unwritten rules can be generated from unwritten sources. The Supreme Court completes the first task admirably. In its basic outlines, the general theory advanced in the Judges Reference and the Secession Reference is bold, clear, and cogent. But the second task is not adequately dealt with. The Supreme Court appears to be uncomfortable with an open acknowledgment of the process of recognizing unwritten rules based on the pragmatic essentials of a democratic constitution and instead places considerable emphasis on the alleged effect of the Preamble. I respectfully submit that this is an unwelcome and disruptive choice that undermines an otherwise impressive constitutional theory. The difficulty is not simply that the Supreme Court does not formally recognize the very methodology that it has been assiduously employing in numerous decisions, but also that the Preamble is not equal to the role demanded of it. I consider the general theory of the Constitution and the mechanism of the Preamble under separate headings.

\section{The ARCHitecture of THE CANADiAn Constitution}

The main components of the Supreme Court's theory of the Constitution can be found in the following passages of the Judges Reference: 
Notwithstanding the presence of s. 11(d) of the Charter, and ss. 96-100 of the Constitution Act, 1867, I am of the view that judicial independence is at root an unwritten constitutional principle, in the sense that it is exterior to the particular sections of the Constitution Acts. The existence of that principle, whose origins can be traced to the Act of Settlement of 1701, is recognized and affirmed by the preamble to the Constitution Act, 1867. The specific provisions of the Constitution Acts, 1867 to 1982, merely "elaborate that principle in the institutional apparatus which they create or contemplate": Switzman.

There are many important reasons for the preference for a written constitution over an unwritten one, not the least of which is the promotion of legal certainty and through it the legitimacy of constitutional judicial review. Given these concerns, which go to the heart of the project of constitutionalism, it is of the utmost importance to articulate what the source of those unwritten norms is.

[T] he preamble does have important legal effects... In the words of Rand J., the preamble articulates "the political theory which the Act embodies": Switzman.... It recognizes and affirms the basic principles which are the very source of the substantive provisions of the Constitution Act, 1867. As I have said above, those provisions merely elaborate those organizing principles in the institutional apparatus they create or contemplate. As such, the preamble is not only a key to construing the express provisions of the Constitution Act, 1867, but also invites the use of those organizing principles to fill out gaps in the express terms of the constitutional scheme. It is the means by which the underlying logic of the Act can be given the force of law. $^{129}$

Three basic propositions can be drawn from these excerpts:

1. Unwritten principles are the source of the entire Canadian Constitution.

2. Authoritative written texts are derived from these principles through a process of formal enactment.

3. Unwritten rules are also derived from these principles through the mechanism of the Preamble.

The Preamble is the significant flaw in this theory. If this discordant element is set aside momentarily, a substantial innovation becomes evident. The Constitution is recognized as including a foundational reservoir of "organizing principles," with both written and unwritten rules emanating from this extra-textual core. Formally enacted rules are always preferable, due to their express democratic source and their greater publicity and "legal certainty." But both written and unwritten rules "merely elaborate" the foundational "organizing principles," and where written rules prove to be unable to protect vital constitutional interests, the courts can respond by determining relevant unwritten rules.

129 Judges Reference, supra note 1 at paras 83, 93, 95 [citations omitted], citing Switzman, supra note 11 at 306 . 
This theory is restated in more detail in the Secession Reference, where the Supreme Court stresses that while texts "have a primary place in determining constitutional rules, they are not exhaustive." 130 The Constitution "embraces unwritten, as well as written rules," and "contain[s] a comprehensive set of rules and principles which are capable of providing an exhaustive legal framework for our system of government":

Our Constitution is primarily a written one, the product of 131 years of evolution. Behind the written word is an historical lineage stretching back through the ages, which aids in the consideration of the underlying constitutional principles. These principles inform and sustain the constitutional text: they are the vital unstated assumptions upon which the text is based.

Our Constitution has an internal architecture, or what the majority of this Court in OPSEU ... called a "basic constitutional structure." The individual elements of the Constitution are linked to the others, and must be interpreted by reference to the structure of the Constitution as a whole. As we recently emphasized in the Provincial Judges Reference, certain underlying principles infuse our Constitution and breathe life into it. Speaking of the rule of law principle in the Manitoba Language Rights Reference ... we held that "the principle is clearly implicit in the very nature of a Constitution." The same may be said of the other three constitutional principles we underscore today.

Although these underlying principles are not explicitly made part of the Constitution by any written provision, other than in some respects by the oblique reference in the preamble to the Constitution Act, 1867, it would be impossible to conceive of our constitutional structure without them. The principles dictate major elements of the architecture of the Constitution itself and are as such its lifeblood. ${ }^{131}$

Written text occupies a central place in the Constitution ("primarily a written one"), but unwritten principles are "the vital unstated assumptions upon which the text is based." The Secession Reference thus reaffirms the repeated assertions made in the Judges Reference that text "merely elaborate[s]." The above passages are also noteworthy in their use of the language of "architecture" and "lifeblood" — the Constitution is a constructed edifice, but one that is internally and organically coherent.

The existence of "vital unstated assumptions" provides authority for courts to look beyond the primacy of the "written word" in circumstances of necessity. The Secession Reference goes significantly further than the Judges Reference in clarifying these circumstances and the legal ramifications of recognizing that unwritten principles form the core of the Constitution:

The principles assist in the interpretation of the text and the delineation of spheres of jurisdiction, the scope of rights and obligations, and the role of our political institutions. Equally important, observance of and 
respect for these principles is essential to the ongoing process of constitutional development and evolution of our Constitution as a "living tree".

Underlying constitutional principles may in certain circumstances give rise to substantive legal obligations (have "full legal force," as we described it in the Patriation Reference...), which constitute substantive limitations upon government action. These principles may give rise to very abstract and general obligations, or they may be more specific and precise in nature. The principles are not merely descriptive, but are also invested with a powerful normative force, and are binding upon both courts and governments. "In other words," as this Court confirmed in the Manitoba Language Rights Reference ... "in the process of Constitutional adjudication, the Court may have regard to unwritten postulates which form the very foundation of the Constitution of Canada."132

The first sentence here stresses that unwritten principles have much more than an ancillary interpretive role in relation to texts. In the six decisions considered above, the Supreme Court is concerned precisely with "the delineation of spheres of jurisdiction, the scope of rights and obligations, and the role of our political institutions." The "substantive legal obligations" recognized in these decisions halt the operation of written texts, regulate the conduct of the parties to the federal union, and overrule legislation. These are legally very significant results, and are traced here to the unwritten sources of foundational authority that govern the development of the entire Constitution.

While the use of unwritten principles to overrule legislation was strongly questioned by Justice La Forest in his forceful dissent in the Judges Reference, ${ }^{133}$ in the Secession Reference, the unanimous Supreme Court closes ranks on this point. ${ }^{134}$ The accent in the above passage on the "full legal force" of the "substantive legal obligations" emerging from unwritten principles is of particular note here. The brief phrase quoted from the Patriation Reference should be read in its entirety. In that earlier decision, Justices Martland and Ritchie, speaking of "judicially developed legal principles and doctrines," stressed that "they have been accorded full legal force in the sense of being employed to strike down legislative enactments." 135 While delivered in dissent, these comments are expressly adopted in the Secession Reference ("as we described it"). ${ }^{136}$ Exempting legislation from the scope of unwritten principles is not consistent with their foundational importance. Unwritten principles define the institutional relationships that are essential to the coherence of democratic mandates. Legislation that threatens such relationships is intolerable and must be subject to the "full legal force" of the relevant unwritten rules. The reference to

Ibid at paras 52,54 [emphasis added] [citations omitted]. The famous reference to the "living tree" is cited to Edwards v Canada (AG), [1930] AC 124 at 136 (PC).

133 See Judges Reference, supra note 1 at paras $314,316,319$.

134 Justice La Forest retired before the Secession Reference. For an express statement in the Judges Reference that the unwritten "constitutional imperative[s]" of "basic structure" can overrule legislation, see ibid at para 108 .

135 Patriation Reference, supra note 7 at 844-45.

136 The dissenting comments from the Patriation Reference are also endorsed by the unanimous Supreme Court in the Manitoba Language Reference, supra note 3 at 752. 
"substantive limitations upon government action" in the last quoted passage from the Secession Reference must be read as embracing the full panoply of official exercises of power. Courts, executives, and legislatures alike must operate within the constraints of the Constitution.

The architectural model of the Constitution provided in both the Judges Reference and the Secession Reference can be easily visualized: an informing core of foundational "organizing principles," with both written and unwritten rules emanating from this core. The foundation supports the rules; the rules build on, develop, and realize the implications of the foundation. This model is consistent with my discussion of the architecture of the democratic state and furthermore, clearly accommodates the methodology of reasoning from constitutional essentials. The Supreme Court does not, however, expressly recognize this methodology in either decision, despite its centrality to both rulings and to the earlier judgments discussed above. The crucial subject of the mechanics by which unwritten rules are drawn from unwritten principles is significantly underdeveloped in the theory of the Constitution presented in the Judges Reference and the Secession Reference. The second major task that I isolated above, in other words, remains outstanding. What little that the Supreme Court does offer in this area is dominated by extremely unsatisfying references to the Preamble.

\section{THE PREAMBUlar MECHANISM}

In the course of his general discussion of the Constitution in the Judges Reference, Chief Justice Lamer states that the Preamble is "the means by which the underlying logic of the Act can be given the force of law." ${ }^{137} \mathrm{He}$ also asserts that it has "important legal effects" and a "special legal effect," and is the "grand entrance hall to the castle of the Constitution."138 This attempt to cast the prefatory language to the Constitution Act, 1867 as the basis on which law can be generated from unwritten principles is fraught with difficulties. I outline four problems below.

First, on a practical level, it must be noted that none of the decisions discussed in this article rely on the Preamble in their use of unwritten principles. The Preamble is present in the Manitoba Language Reference, and is briefly alluded to in MacMillan Bloedel, but in neither case does it perform a clear gatekeeping function in the sense of controlling access to unwritten principles. ${ }^{139}$ The same is true of the obiter passage from OPSEU and the detailed analyses that resolve the Judges Reference and the Secession Reference. Indeed, in the latter decision, the discussion of the four unwritten principles extends for almost 30 paragraphs, and the application of those principles extends for another 20 paragraphs. The Preamble is not mentioned once in the course of this material. In New Brunswick

Judges Reference, supra note 1 at para 95.

Ibid at paras 95, 104, 109.

Manitoba Language Reference, supra note 3 at 750; MacMillan Bloedel, supra note 6 at para 37. In the latter decision, the reference to the Preamble is only in passing. The Preamble is also not considered by Chief Justice Lamer in his extra-judicial article addressing the primacy of the rule of law in resolving MacMillan Bloedel: Lamer, supra note 47. 
Broadcasting, it is true that parliamentary privilege is "constitutionalized by virtue of this preamble." ${ }^{140}$ But there is no suggestion that the "pragmatic" argument, which I argued above is the real core of the decision, must pass through the "grand entrance hall" in order to function.

Second, the claim that the Preamble is "the means by which the underlying logic of the Act can be given the force of law" runs into difficulties on a conceptual level. It seems inconsistent to give a piece of writing a determinative role in a theory of unwritten constitutionalism predicated on the notion that texts are not exhaustive or definitive (the latter point being stressed in passages quoted above from each of New Brunswick Broadcasting, the Judges Reference, and the Secession Reference). Surely a Constitution defined by written and unwritten rules cannot have a written "grand entrance hall." Rather, there are numerous modes of ingress, some drawing on written sources and some drawing on the "pragmatic" implications of structure.

Third, the uncertain legal status of the Preamble continues to undermine the Supreme Court's attempt to press it into service as a mechanism for generating law. As I noted in my discussion of New Brunswick Broadcasting, preambles are informal: they are essentially nonposited and have "no enacting force," as the Supreme Court explained in the Patriation Reference. ${ }^{141}$ Chief Justice Lamer does acknowledge this point in the Judges Reference, but he does little to counter it other than to state that the "preamble articulates 'the political theory which the Act embodies." "142 It is difficult to see how articulating a political theory can bridge the gap between posited and non-posited text and thereby lead to a "special legal effect." The methodology of reasoning from constitutional essentials can involve articulating a political theory, and in the appropriate circumstances, legal consequences may result from this reasoning. But the links in the chain are all provided by legal argumentation. The Preamble, on the other hand, appears somehow to offer a shortcut, predicated on its quasiwritten status. It thus exists in some uncertain space between text and non-text. Such uncertainty is not welcome in a theory of the Constitution authorizing the dramatic legal results that flow from the decisions discussed above.

Fourth, the very suggestion that the Preamble "articulates" raises a central linguistic difficulty. A court applying the Preamble must confront the crucially vague phrase "a Constitution similar in Principle to that of the United Kingdom." How much space can be traversed by the words "similar in Principle to" before the Preamble is pushed beyond the bounds of legitimate argument? In other words, what exactly is articulated by the Preamble? ${ }^{143}$ The issue before the Supreme Court in the Judges Reference reveals the importance of this question. Justice La Forest, in his dissent, observed that the inferior courts

SM Corbett maintains that " $[\mathrm{t}]$ he sense in which Canada ever had a constitution similar in principle to that of the United Kingdom is, and should be, a matter of debate": SM Corbett, "Reading the Preamble to the British North America Act, 1867' (1998) 9:2 Const Forum Const 42 at 43. 
did not enjoy constitutional protection in the United Kingdom in 1867 and further, that acts of Parliament have never been subject to judicial review in the United Kingdom on the basis of the principle of judicial independence. ${ }^{144}$ These are powerful observations, but "similar in Principle to" may be sufficient to carve out room for a different interpretation in Canada. ${ }^{145}$ The existence of fundamental uncertainty as to the content of the Preamble undermines the coherence of relying on it as a mechanism for generating legal consequences from unwritten principles. The Preamble is an uncertain signifier pointing to an uncertain signified. It should not be granted a privileged place in a theory of the Constitution.

The Secession Reference expressly endorses the claims made about the Preamble in the Judges Reference ${ }^{146}$ but does so only briefly, and, as I noted above, the Supreme Court in the later decision makes no use of the Preamble in the course of the extensive discussion of the four foundational principles. The Secession Reference also provides the following passing reference that can be read as a retreat from the enthusiastic claims of a "special legal effect" and a "grand entrance hall" in the Judges Reference:

\footnotetext{
Although these underlying principles are not explicitly made part of the Constitution by any written provision, other than in some respects by the oblique reference in the preamble to the Constitution Act, 1867, it would be impossible to conceive of our constitutional structure without them. ${ }^{147}$
}

The vague phrases here — "some respects," "oblique reference" — support the view that the Preamble brings very little to the table. I suggest that the entire middle portion of the sentence in the above passage can be removed with no damage to the cogency of the Supreme Court's theory of the Constitution. The important point is the pragmatic requirements of "our constitutional structure." As the Supreme Court observes in a passage from the Secession Reference quoted previously,

[s]peaking of the rule of law principle in the Manitoba Language Rights Reference, we held that "the principle is clearly implicit in the very nature of a Constitution". The same may be said of the other three constitutional principles we underscore today. ${ }^{148}$

Everything that is needed for a compelling legal argument is already "implicit in the very nature of a Constitution." The methodology of reasoning from constitutional essentials, and not the "oblique" Preamble, is the appropriate way to generate unwritten rules from foundational constitutional principles.

Judges Reference, supra note 1 at paras $308,311,313,321$.

Chief Justice Lamer emphasizes the considerable evolution that has occurred in Canada since 1867 (ibid at paras 89,106$)$.

Secession Reference, supra note 2 at para 51.

Ibid at para 51.

Ibid at para 50 [citation omitted]. 


\section{Conclusion: The Supreme Court's Unfinished UnWritten Principles Project}

The judgments considered in this article mark a particularly significant phase of Canadian constitutional development in which the use of extra-textual sources of authority gains considerable momentum and cohesion. In these decisions, the Supreme Court draws on unwritten principles to resolve difficult questions. The legal results are dramatic and include the overruling of legislation, the halting of constitutional texts, and the imposition of obligations on federal and provincial governments.

In the Judges Reference and the Secession Reference, the Supreme Court goes beyond employing unwritten principles in constitutional analysis and reflects upon the shape of the Constitution in light of the existence of extra-textual sources of authority. The Supreme Court outlines a structural model that consists of an informing core of foundational "organizing principles," with both written and unwritten rules emanating from this core. In keeping with the architectural language used in many of the decisions, it can be said that written and unwritten rules are the bulwarks and ramparts of the edifice of the Constitution, while the unwritten principles are the foundation of that edifice.

With the theoretical inroads made in the Judges Reference and the Secession Reference, it becomes possible to speak of a conscious unwritten principles project that informs the evolution of the Canadian Constitution. However, one significant deficiency in the Supreme Court's theory is the lack of a convincing account of how unwritten rules are actually generated from unwritten principles. While the Preamble is advanced as a mechanism, this proposition raises too many difficulties to be satisfactory. A more appropriate explanation for the formulation of unwritten rules can be found in the conceptual coherence of the overall structure of the Constitution itself. While written norms (constitutional or legislative) are posited through exercises of popular will, unwritten norms can be generated through judicial reflection on the necessary interrelationships of the various components of constitutional architecture. This process of reasoning is ultimately "pragmatic" (to borrow Justice McLachlin's term from New Brunswick Broadcasting) and looks to what Walters calls the "practical legal implications" of fundamental choices made in the design of the overall system of government. The methodology of reasoning from constitutional essentials, as I have called this form of interpretation, identifies an unwritten rule that must follow if the global structure of the Constitution is to have any efficacy. Such a rule must be counted as fully authoritative and, as Black observes, "arises by necessary implication ... as clearly as though it had been specifically stated in the Constitution.",149

Recourse to the methodology of reasoning from constitutional essentials is appropriate when there are significant threats to the structure of the Constitution. In such circumstances, where authoritative written texts do not provide an adequate response, the courts, in their role 
as "the guardian of the Constitution," "150 can legitimately probe underlying logic in order to understand the nature of the threat and determine whether there is a mandated unwritten response.

Crucially, the methodology of reasoning from constitutional essentials is employed by the Supreme Court itself in each of the decisions discussed above. Thus, while the Supreme Court's unwritten principles project remains incomplete without a clear statement of how unwritten rules are generated from unwritten sources of authority, there is no need to make radical alterations in existing doctrine to close the gap (other than some marginalizing of the Preamble). The great achievement of the Supreme Court in all of the decisions considered above is employing legal reasoning from constitutional essentials to respond to threats to our system of government. The great achievement of the Supreme Court in the Judges Reference and the Secession Reference is beginning the process of theorizing the overall architecture of the Constitution. It is time to bring these two achievements together. 
[this page is intentionally blank] 